\title{
Cell survival, cell death and cell cycle pathways are interconnected: Implications for cancer therapy
}

\author{
Subbareddy Maddika ${ }^{\text {a,c,1 }}$, Sudharsana Rao Ande ${ }^{\text {a, }}$, Soumya Panigrahi ${ }^{\text {a,e }}$, \\ Ted Paranjothy a , Kazimierz Weglarczyk ${ }^{\mathrm{a}, \mathrm{f}}$, Anne Zuse ${ }^{\mathrm{a}}$, Mehdi Eshraghi a,c, \\ Kamala D. Manda ${ }^{d}$, Emilia Wiechec ${ }^{a, g}$, Marek Los ${ }^{a, b, c, *}$ \\ a Manitoba Institute of Cell Biology, CancerCare Manitoba, University of Manitoba, Winnipeg, Canada \\ ${ }^{\mathrm{b}}$ Department of Human Anatomy and Cell Biology, University of Manitoba, Winnipeg, Canada \\ ${ }^{c}$ Department of Biochemistry and Medical Genetics, University of Manitoba, Winnipeg, Canada \\ ${ }^{\mathrm{d}}$ Department of Immunology, University of Manitoba, Winnipeg, Canada \\ e Department of Physiology, University of Manitoba, Winnipeg, Canada \\ ${ }^{\mathrm{f}}$ Department of Clinical Immunology, Polish-American Institute of Pediatrics, Jagiellonian University Medical College, Krakow, Poland \\ g Department of Human Genetics, University of Aarhus, DK-8000 C Aarhus, Denmark
}

Received 30 December 2006; received in revised form 26 January 2007; accepted 26 January 2007

\begin{abstract}
The partial cross-utilization of molecules and pathways involved in opposing processes like cell survival, proliferation and cell death, assures that mutations within one signaling cascade will also affect the other opposite process at least to some extent, thus contributing to homeostatic regulatory circuits. This review highlights some of the connections between opposite-acting pathways. Thus, we discuss the role of cyclins in the apoptotic process, and in the regulation of cell proliferation. CDKs and their inhibitors like the INK4-family (p16 ${ }^{\text {Ink4a }}, \mathrm{p} 5^{\text {Ink4b }}$, $\mathrm{p} 18^{\text {Ink4c }}, \mathrm{p} 19^{\text {Ink4d }}$ ), and the Cip1/Waf1/Kip1-2-family (p21 ${ }^{\text {Cip1/Waf1 }}, \mathrm{p} 27^{\text {Kip1 }}, \mathrm{p} 57^{\text {Kip2 }}$ ) are shown both in the context of proliferation regulators and as contributors to the apoptotic machinery. Bcl2-family members (i.e. Bcl2, Bcl- $\mathrm{X}_{\mathrm{L}} \mathrm{Mcl}-1_{\mathrm{L}}$; Bax, Bok/Mtd, Bak, and Bcl-X $\mathrm{X}_{\mathrm{S}}$; Bad, Bid, $\mathrm{Bim}_{\mathrm{EL}}, \mathrm{Bmf}, \mathrm{Mcl}-1_{\mathrm{S}}$ ) are highlighted both for their apoptosis-regulating capacity and also for their effect on the cell cycle progression. The PI3-K/Akt cell survival pathway is shown as regulator of cell metabolism and cell survival, but examples are also provided where aberrant activity of the pathway may contribute to the induction of apoptosis. Myc/Mad/Max proteins are shown both as a powerful S-phase driving complex and as apoptosis-sensitizers. We also discuss multifunctional proteins like p53 and Rb (RBL1/p107, RBL2/p130) both in the context of $\mathrm{G}_{1}-\mathrm{S}$ transition and as apoptotic triggers. Finally, we reflect on novel therapeutic approaches that would involve redirecting over-active survival and proliferation pathways towards induction of apoptosis in cancer cells.
\end{abstract}

(C) 2007 Elsevier Ltd. All rights reserved.

Abbreviations: AIF, apoptosis inducing factor; ANT, adenine nucleotide translocator; Apaf1, apoptosis activating factor 1; BH3, bcl2-homology domain 3; MDM2, mouse double minute 2; MYT1, membrane-associated and tyrosine/threonine-specific-1; VDAC, voltage-dependent anion channel * Corresponding author at: Manitoba Institute of Cell Biology, ON6010675 McDermot Ave., University of Manitoba, Winnipeg, Man. R3E 0V9, Canada. Tel.: +1 204787 2294(O)/1403 (lab)/4108 (lab);

fax: +1 2047872190 .

E-mail address: losmj@cc.umanitoba.ca (M. Los).

1 Authors contributed equally to this review manuscript.

\section{General introduction: linking cell cycle, cell survival and cell death}

Molecular linkages between cell death, cell survival, and cell cycle have become an object of intense research in recent years (Table 1). The standard eukaryotic cell cycle is divided into four non-overlapping phases, with DNA synthesis and mitosis occurring during $\mathrm{S}$ phase and $\mathrm{M}$ phase, respectively. These landmark events are separated by $\mathrm{G}_{1}$ and $\mathrm{G}_{2}$ gap phases during which mRNAs and proteins accumulate continuously. 
Table 1

Examples of molecules with dual or triple functions (cell cycle/apoptosis/cell survival and/or proliferation)

\begin{tabular}{|c|c|c|c|}
\hline Molecule & Cell cycle function & Apoptotic function & Cell survival/proliferation \\
\hline \multicolumn{4}{|l|}{ Cyclins } \\
\hline Cyclin A & $\begin{array}{l}\text { Positive regulator of G1/S transition } \\
\text { (Girard et al., 1991) }\end{array}$ & $\begin{array}{l}\text { Promotes apoptosis (Hoang et al., } \\
\text { 1994; Meikrantz et al., 1994) }\end{array}$ & $\begin{array}{l}\text { Enhances the cell survival (Hunter } \\
\text { and Pines, 1991) }\end{array}$ \\
\hline Cyclin E & $\begin{array}{l}\text { Promotes the G1 phase progression } \\
\text { (Koff et al., 1991) }\end{array}$ & $\begin{array}{l}\text { Positive role during apoptosis } \\
\text { (Mazumder et al., 2002) }\end{array}$ & $\begin{array}{l}\text { Required for cell survival and cell } \\
\text { proliferation (Dobashi, 2005) }\end{array}$ \\
\hline Cyclins D1/D2/D3 & $\begin{array}{l}\text { Promotes entry into G1 phase } \\
\text { (Schwartz and Shah, 2005) }\end{array}$ & $\begin{array}{l}\text { Positive and negative regulator of } \\
\text { apoptosis (Kranenburg et al., 1996; } \\
\text { Biliran et al., 2005) }\end{array}$ & $\begin{array}{l}\text { Promotes cell survival (Hinds et al., } \\
\text { 1994) }\end{array}$ \\
\hline Cyclin B1/B2 & $\begin{array}{l}\text { Positive regulator of G2/M phase } \\
\text { (Pines and Hunter, 1989) }\end{array}$ & $\begin{array}{l}\text { Positively involved in apoptosis } \\
\text { (Porter et al., 2000; Borgne et al., } \\
\text { 2006; Huang et al., 2006) }\end{array}$ & $\begin{array}{l}\text { Promotes cell survival and } \\
\text { proliferation (Coqueret, 2003) }\end{array}$ \\
\hline Cyclin G & Positively regulates G1/S phase? & $\begin{array}{l}\text { Positive role in apoptosis (Okamoto } \\
\text { and Prives, 1999) }\end{array}$ & $\begin{array}{l}\text { Positively promotes cell growth } \\
\text { (Smith et al., 1997) }\end{array}$ \\
\hline \multicolumn{4}{|l|}{ CDKS } \\
\hline CDK1 & $\begin{array}{l}\text { Positively regulates both G2/M and } \\
\text { G1/S phases (Morgan, 1997) }\end{array}$ & $\begin{array}{l}\text { Positive role in apoptosis (reviewed } \\
\text { in Ref. Golsteyn, 2005) }\end{array}$ & $\begin{array}{l}\text { Promotes cell proliferation } \\
\text { (Wolowiec et al., 1995) }\end{array}$ \\
\hline CDK2 & $\begin{array}{l}\text { Positively regulates G1/S phase } \\
\text { (Morgan, 1997) }\end{array}$ & $\begin{array}{l}\text { Positively involved in apoptosis } \\
\text { (reviewed in Ref. Golsteyn, 2005) }\end{array}$ & $\begin{array}{l}\text { Promotes cell proliferation but tot } \\
\text { required for cell survival (Berthet et } \\
\text { al., 2003) }\end{array}$ \\
\hline \multicolumn{4}{|l|}{ CDKIs } \\
\hline $\begin{array}{l}\text { INK4 family (p16 } 6^{\text {Ink 4a }} \\
\text { p15 } \\
\left.\text { p1 } 19^{\text {Ink } 4 \mathrm{~b}} 4 \mathrm{p}\right)\end{array}$ & $\begin{array}{l}\text { Negatively regulates G1/S phase } \\
\text { (Carnero and Hannon, 1998) }\end{array}$ & $\begin{array}{l}\text { Negatively regulates apoptosis } \\
\text { (Ivanchuk et al., 2001) }\end{array}$ & $\begin{array}{l}\text { Inhibits cell proliferation (Sherr, } \\
\text { 2001) }\end{array}$ \\
\hline $\begin{array}{l}\text { Cip/Kip family } \\
\left(\mathrm{p} 21^{\text {Cip} 1 / \text { Waf1 }}, \mathrm{p} 27^{\mathrm{Kip} 1}\right. \\
\text { p5 }\end{array}$ & $\begin{array}{l}\text { Negatively regulates G1/S phase } \\
\text { (Hengst and Reed, 1998) }\end{array}$ & $\begin{array}{l}\text { Positive and negative regulators of } \\
\text { apoptosis (Gartel, 2005; Hiromura et } \\
\text { al., 1999) }\end{array}$ & $\begin{array}{l}\text { Inhibits cell prolilferation (Hengst } \\
\text { and Reed, 1998) }\end{array}$ \\
\hline PI3K/Akt Pathway & $\begin{array}{l}\text { Promotes cell cycle progression at } \\
\text { G1/S and G2 phases (reviewed in } \\
\text { Ref. Liang and Slingerland, 2003) }\end{array}$ & $\begin{array}{l}\text { Mainly negative regulators of } \\
\text { apoptosis but also shown to be } \\
\text { positive under certain conditions } \\
\text { (Brunet et al., 1999; Aki et al., 2003; } \\
\text { Lee et al., 2005; Lu et al., 2006; } \\
\text { Nimbalkar et al., 2003; Ono et al., } \\
\text { 2004; Shack et al., 2003) }\end{array}$ & $\begin{array}{l}\text { Promotes cell survival and } \\
\text { proliferation (reviewed in Ref. } \\
\text { Vivanco and Sawyers, 2002) }\end{array}$ \\
\hline \multicolumn{4}{|l|}{ Bcl-2 family } \\
\hline $\begin{array}{l}\text { Bcl-2, Bcl-xL, MCl-1, } \\
\text { Bcl-w }\end{array}$ & $\begin{array}{l}\text { Delays cell cycle entry and G1/S } \\
\text { (Greider et al., 2002; Vairo et al., } \\
\text { 2000) }\end{array}$ & Negatively regulates apoptosis & $\begin{array}{l}\text { Enhances the cell survival (Cory and } \\
\text { Adams, 2002) }\end{array}$ \\
\hline Bax, Bad, Bid, Bok & $\begin{array}{l}\text { Inhibits cell cycle progression } \\
\text { (reviewed in Ref. Zinkel et al., 2006) }\end{array}$ & $\begin{array}{l}\text { Positively regulates apoptosis } \\
\text { (reviewed in Ref. Reed, 1997) }\end{array}$ & $\begin{array}{l}\text { Inhibits the cell survival (Antonsson } \\
\text { and Martinou, 2000) }\end{array}$ \\
\hline Myc family & $\begin{array}{l}\text { Promotes G1/S progression (Steiner } \\
\text { et al., 1996; Bernard and Eilers, } 2006\end{array}$ & $\begin{array}{l}\text { Positive and negative regulator of } \\
\text { apoptosis (Desbarats et al., 1996; } \\
\text { Alarcon et al., 1996; Spencer and } \\
\text { Groudine, 1991; Dong et al., 1997; } \\
\text { Rupnow et al., 1998) }\end{array}$ & $\begin{array}{l}\text { Promotes cell proliferation (Borg et } \\
\text { al., 1992; Jenkins et al., 1997; } \\
\text { Watson, 2006) }\end{array}$ \\
\hline
\end{tabular}

In $\mathrm{G}_{1}$ phase the cell is preparing for DNA synthesis, the cell is growing and the diploid cell has $2 \mathrm{n}$ chromosomes (Collins and Garrett, 2005; Schafer, 1998). In the subsequent $S$ phase, DNA duplication occurs and at the end of the phase the DNA content has reached $4 \mathrm{n}$. Before cells undergo mitosis, they continue in the $G_{2}$ phase with cell growth and are thus prepared for cell division. During mitosis separation into two daughter cells occurs. Cells which are in $\mathrm{G}_{0}$ phase (quiescence) are not actively cycling (Collins and Garrett, 2005). To avoid inappropriate cell proliferation, control mechanisms exist. The key regulator proteins which allow the transition from one cell cycle phase to another are called cyclin-dependent kinases (CDKs), a fam- ily of serine/threonine protein kinases which are activated at specific points during cell cycle (Collins and Garrett, 2005; Vermeulen et al., 2003). Positive regulation of CDK activity occurs through association with a second subunit, the cyclin and by phosphorylation of the T-loop threonine by a CDKactivating kinase (Park and Lee, 2003). Cyclins are produced at each of these phases and form a complex with their CDK partners. The levels of activating cyclins in different stages of the cell cycle differ, whereas the CDK protein levels remain stable (Vermeulen et al., 2003). During the $\mathrm{G}_{0}$ to $\mathrm{S}$ phase transition, cyclins D1, D2, D3 and C get activated. Cyclins D1, D2, and D3 bind to CDK4 and CDK6 where as cyclin $\mathrm{C}$ binds to CDK8. Cyclins D1, D2, D3 are the first cyclins 
to be induced as the $\mathrm{G}_{0}$ cells are stimulated to enter the cell cycle. The progression through $\mathrm{G}_{1}$ is mediated by cyclin $\mathrm{D}$ isoforms and CDK2, -4, and -6 (Schwartz and Shah, 2005; Vermeulen et al., 2003). Cyclin $E$ is associated during $G_{1}$ to $\mathrm{S}$ phase transition and activates CDK2. Cyclin A gets activated during the $S$ phase transition and binds to $C D K 1$ and CDK2. B type cyclins are present during $\mathrm{G}_{2}$ exit and mitosis phase and are associated with CDK1 (Coqueret, 2003). $\mathrm{G}$ and $\mathrm{T}$ type cyclins are associated with CDK5 and CDK9, respectively (Johnson and Walker, 1999).

Defects in cell cycle regulation can result in cancerous growth and developmental abnormalities. Therefore, insight into mechanisms of dysregulation in cell division can provide strategies for designing novel anti-cancer agents. Cell-cycle progression is a highly organized and tightly regulated process that controls cell growth, cell proliferation, and ontogenesis and is well connected to the regulation of DNA damage repair (Panigrahi and Mai, 2005; Schwartz and Shah, 2005). CDKs, the key regulator proteins, which in connection with their positive regulators, cyclins, allow the transition from one cell cycle phase to another, are also tightly regulated by inhibitory phosphorylation and by inhibitory molecules. The inhibitory phosphorylation is mediated by the kinase Wee1 and MYT1 (Park and Lee, 2003). CDKs can also be inhibited by two classes of CDK inhibitors, the INK4 group such as $\mathrm{p} 16^{\text {Ink4a }}$ or $\mathrm{p} 15^{\text {Ink4b }}$ and the CIP/KIP class such as p21 $1^{\text {waf1 }}$ or p27 ${ }^{\text {kip } 1}$ (Park and Lee, 2003; Grant and Roberts, 2003; Schwartz and Shah, 2005).

Each phase of the cell cycle contains checkpoints that allow the arrest of the cell cycle progression and activation of repair mechanisms. After passing these checkpoints cells are irreversibly committed to the next phase (Park and Lee, 2003). DNA damage and/or malfunction of other critical organelles or structures (e.g. faulty mitotic spindle) can activate the cell cycle arrest and even the apoptotic cascade, leading to cell death (Rowinsky, 2005; Siegel, 2006). Thus, the apoptotic machinery is an essential element of cell cycle checkpoints, protecting the integrity of multicellular organisms and allowing for selective removal of unwanted or damaged cells (Khosravi-Far and Esposti, 2004; Los and Gibson, 2005; Los et al., 1999). Apoptosis also plays an important role in the embryonic development, during the regulation of the immune response and in tissue homeostasis (Booy et al., 2005; Khosravi-Far and Esposti, 2004; Okada and Mak, 2004; Oliver and Vallette, 2005). The induction of programmed cell death occurs via two major pathways: the death receptor-dependent (extrinsic) pathway through TNFfamily ligands, or via the mitochondrial (intrinsic) pathway induced by different factors such as UV radiation, chemotherapeutics, free radicals or DNA damage (Brouckaert et al., 2005; Los et al., 1995; Maddika et al., 2006). The induction of apoptosis leads to cell blebbing, exposure of phosphatidylserine at the cell surface, reduction of cell size, shrinkage of the cell core, DNA condensation and the formation of apoptotic bodies (Darzynkiewicz et al., 1997; Khosravi-Far and Esposti, 2004).
The death-receptor pathway is activated through the binding of cytokine ligands to receptors of the TNF-superfamily such as CD95/Apo-1/Fas, or TRAIL (Blagosklonny and Darzynkiewicz, 2005; Okada and Mak, 2004; Wesselborg and Lauber, 2005). The receptors contain different death effector domains (DEDs). Upon ligand binding, the receptors aggregate and form membrane-bound signaling complexes (Brouckaert et al., 2005). These are responsible for the recruitment of several molecules of the initiator pro-caspase8 through adaptor molecules such as Fas-associated death domain (FADD). This event results in the formation of the death-induced signaling complex (DISC), activation of caspase- 8 (cysteinyl aspartate-specific protease) and triggering the proteolytic caspase cascade (Brouckaert et al., 2005). Alternatively active caspase- 8 can cleave the Bcl2-homology domain 3 (BH3) of the protein BID (BH3-interacting-domain death agonist) into the active form tBid (truncated BID) which provides a cross-talk between the extrinsic (death receptor-activated) and intrinsic (mitochondrial) pathway (Khosravi-Far and Esposti, 2004; Siegel, 2006). Cleaved Bid acquires a strong propensity to mitochondria and promotes the mitochondrial permeability transition (Hengartner, 2000). The mitochondrial pathway can also be triggered by various intracellular and extracellular stress signals which result in activation of pro-apoptotic proteins such as Bcl2associated $\mathrm{X}$ protein (Bax) and $\mathrm{Bcl} 2$ antagonist/killer (Bak), or inactivation of anti-apoptotic Bcl 2 family members such as $\mathrm{Bcl} 2$ or Bcl- $\mathrm{x}_{\mathrm{L}}$ (Brouckaert et al., 2005; Finkel, 2001). Also, members of the $\mathrm{Bcl} 2$ family such as $\mathrm{Bcl} 2$, Bax and Bak may localize to the ER. Through the mitochondriaER connection a further important control mechanism of apoptosis exists that either rely on caspase- 2 as the apical caspase or connect to the mitochondrial death pathway over cellular-stress-signaling mechanisms (Kim et al., 2006). Anti-apoptotic proteins can be blocked by binding with BH3only proteins such as Bad and Bim (Huang, 2000; Mendoza et al., 2005). Further proapoptotic members of the third class of Bcl 2 family proteins are Bid, Noxa and Puma, which require Bax and Bak to mediate cell death. Bad and Bik cannot directly activate Bak and Bax, but act as sensitizers through binding to $\mathrm{Bcl} 2$ and $\mathrm{Bcl}-\mathrm{X}_{\mathrm{L}}$ (Kim et al., 2006). Bad-like BH3 domains are able to dissociate Bax and Bak from $\mathrm{Bcl} 2$ and $\mathrm{Bcl}-\mathrm{x}_{\mathrm{L}}$. Activation of the dissociated pro-apoptotic molecules occurs by Bid-like activators (Kim et al., 2006). As a result of activation/inactivation of $\mathrm{Bcl} 2$ family proteins, changes in the mitochondrial membrane lead to the dissipation of inner membrane potential and the permeabilization of the outer mitochondrial membrane which in turn induce the release of various proapoptotic proteins such as cytochrome c, Smac, AIF (apoptosis inducing factor), HtrA2, and Endo-G (Endonuclease G) (Barczyk et al., 2005; Brouckaert et al., 2005; Hengartner, 2000).

p53 has tumor-suppressor activity and promotes the expression of several genes involved in apoptosis (Kim et al., 2006; Rowinsky, 2005). Induction of p53-dependent apopto- 
sis proceeds through the downstream release of cytochrome $\mathrm{c}$ from mitochondria. There are various models for the opening of the permeability transition pore which allows the release of the apoptogenic proteins (Rowinsky, 2005). One possibility is that oligomerized Bak or Bax generate pores sufficient for release of the factors (Antonsson and Martinou, 2000). The proapoptotic members might be able to form complexes with mitochondrial membrane proteins such as VDAC or ANT to build pores (Loeffler and Kroemer, 2000). Further explanations are that pores are regulated by misfolded proteins and chaperones or that matrix swelling causes distortion of cristae structure and rupture of outer mitochondrial membrane (Kim et al., 2006). Once released from mitochondria, cytochrome $\mathrm{c}$ is bound by Apaf-1 (apoptotic protease activating factor-1) via the WD40 domain and Apaf1 becomes competent to recruit pro-caspase- 9 in the presence of ATP/dATP. Through a conformational change, the apoptosome is formed and activation of caspase- 9 is mediated (Brouckaert et al., 2005; Philchenkov et al., 2004). Caspase-9 leads to activation of effector pro-caspases, such as caspase3 and caspase-7 (Rowinsky, 2005). Furthermore, released apoptogenic factors are Smac/Diabolo and Omi/Htr2A which can promote caspase activation by counteracting inhibitor of apoptosis (IAP)-mediated caspase inhibition (Cassens et al., 2003; Philchenkov et al., 2004). Endo-G and AIF might induce caspase-independent cell death and produce DNA fragmentation (Kim et al., 2006). The elimination of damaged and unwanted cells in organisms is a result of several apoptogenic factors and cascades. The mechanisms by which apoptosis occur, how it is counteracted, and how the process is linked to cell cycle is discussed below.

\section{PI3-Kinase/Akt pathway controls cell survival, cell cycle and apoptosis}

The Phosphatidylinositol 3'-kinase (PI3-K)/Akt signaling pathway is regarded as one of the key pro-survival pathways within the cell. It is activated by many types of cellular stimuli - but also by toxic insults - and regulates fundamental cellular functions such as proliferation, growth, transcription, translation, cell cycle and also apoptosis (Cantley, 2002; Vanhaesebroeck and Alessi, 2000). Notably, it has been shown that PI3-K/Akt signaling is frequently disrupted in human cancers and plays a major role not only in tumor growth but also in the response to cancer treatment (Vivanco and Sawyers, 2002). PI3-K is a heterodimer composed of a catalytic subunit (p110) and an adapter/regulatory subunit (p85). The p85 subunit bound to $\mathrm{p} 110$ has both a repressor and activator function depending on its conformation. The activation of PI3-K occurs via two different mechanisms, one involving the tyrosine kinase receptor dimerization and auto-phosphorylation, the other involving intracellular nonreceptor tyrosine kinases. The activated PI3-K converts the lipid PI $(4,5)$ P2 to PI $(3,4,5)$ P3 by phosphorylating the substrate at the C3-position of the inositol ring. The serine/threonine kinases PDK1 (3'-phosphoinositide dependent kinase 1) and Akt preferentially bind to PIP3 via their PH domains, which lead to Akt activation depending on its phosphorylation at Ser473 and Thr308 sites by PDK1 (Cuevas et al., 2001; Fruman et al., 1998). Phosphatase and tensin homolog (PTEN), also known as mutated in multiple advanced cancers (MMAC1) converts PIP3 to PIP2 and acts as a negative regulator of the PI3-K pathway (Stambolic et al., 1998). PTEN is considered to be the second most mutated gene in different cancers (Ali et al., 1999). Activated Akt (or PKB) is an important and central downstream effector of the PI3-K pathway (Marte and Downward, 1997). Akt has been estimated to have nearly 900 potential substrates in the cell and modulate their different biological functions both in the cytoplasm and the nucleus. Below, we will focus only on Akt substrates related to survival, cell cycle and apoptosis.

\subsection{Inhibition of apoptosis by Akt}

An important function of activated PI3-K/Akt in cells is maintaining cell survival via inhibition of apoptosis. Akt regulates the process of cell survival by phosphorylating different substrates that directly or indirectly regulate the apoptotic program. Some of the important targets for Akt during this process involve the phosphorylation of BAD (a pro-apoptotic Bcl2 family member), caspase-9, FKHRL1 (a fork head transcription factor), IKK, MDM2 and cyclic AMP response binding protein. Akt mediated phosphorylation of BAD at Ser136 promotes cell survival by inhibiting its interaction with the anti-apoptotic Bcl2 family members like $\mathrm{Bcl}-\mathrm{xL}$ and further preventing the cytochrome c release (Datta et al., 1997). Akt also phosphorylates caspase-9 at Ser196, thus causing a conformational change that leads to the inhibition of its proteolytic activity (Cardone et al., 1998). Akt also indirectly regulates apoptosis by phosphorylating a forkhead transcription factor FKHRL1, and thus inhibiting the transcription of its targets FasL, Bim, IGFBP1 and Puma (Brunet et al., 1999; Guo et al., 1999; Kops et al., 1999; You et al., 2006). Akt also promotes cell survival via activation of NF- $\mathrm{BB}$ by phosphorylating IKK $\alpha$, which in turn phosphorylates, and triggers the degradation of I $\mathrm{B}$, an NFкB inhibitor (Kane et al., 1999; Romashkova and Makarov, 1999). This leads to further elevation in transcription of NF- $\kappa \mathrm{B}$ dependent survival genes (Bcl-xL, Bcl2, c-IAPs, cFLIP) (Catz and Johnson, 2001; Lee et al., 1999; Wang et al., 1998). Akt-mediated phosphorylation of cyclic AMPresponse-element-binding protein (CREB) also enhances survival by increasing transcription of pro-survival genes like Bcl2, Mcl-1 and Akt itself (Pugazhenthi et al., 2000; Reusch and Klemm, 2002; Wang et al., 1999). Furthermore, Akt negatively regulates apoptosis by enhancing the degradation of p53 via phosphorylation, promoting nuclear localization and p53 binding of MDM2, a negative regulator of p53 (Mayo and Donner, 2001). 


\subsection{PI3-K/Akt pathway and cell cycle progression}

In addition to its regulatory role in cell survival, the PI3K/Akt pathway has been suggested to have a key role in cell cycle progression. The PI3-K pathway is activated during two phases of the cell cycle, at first during early $G_{1}$ phase and the second wave of PI3-K activity is during late $\mathrm{S}$ phase (Jones et al., 1999). Many studies have demonstrated the functional significance of PI3-K activation during $\mathrm{G}_{1} / \mathrm{S}$ transition, but the significance of the second wave of activation is not completely known. During $G_{1} / S$ phase transition, the PI3-K/Akt pathway has multiple substrates involving - but not limited to - cyclin D, Myc, p2 $7^{\mathrm{kip} 1}$ and $\mathrm{p} 21^{\mathrm{waf} 1}$. Akt regulates the level of cyclin D1 and Myc proteins by preventing their proteosomal degradation. GSK3 $\beta$ phosphorylates cyclin D1 at Thr286 (Diehl et al., 1998) and Myc at Thr58 (Gregory et al., 2003), which promotes their degradation via ubiquitin-mediated pathway. Thus, Akt by phosphorylating and inactivating its substrate GSK3 $\beta$, prevents the degradation and cytoplasmic relocation of cyclin D1 and Myc, which then facilitates the $\mathrm{G}_{1} / \mathrm{S}$ progression. Akt also regulates the $G_{1} / S$ transition by controlling the cell cycle inhibitors $\mathrm{p} 27^{\mathrm{kip} 1}, \mathrm{p} 21^{\text {waf } 1}$ both at their transcriptional and the post-translational levels. Akt enhances the degradation of p27 by the proteasome-dependent pathway by upregulating SKP2 mRNA levels. SKP2 is a key component of the SCF/SKP2 ubiquitin ligase that mediates p27 degradation in a cyclin E/CDK2 dependent phosphorylation (Hara et al., 2001; Mamillapalli et al., 2001; Pagano et al., 1995). Previously it was shown that Akt-mediated phosphorylation of p27 at thr-157 also causes the relocation of p27 to the cytoplasm, thus relieving the nuclear substrates from p27 inhibition and enhancing the cell cycle progression (Shin et al., 2002). Recently, we have shown that p27 degradation is also regulated and dependent on its direct phosphorylation by Akt at Thr157 (Maddika and Los, submitted for publication). It has also been reported that p27 is regulated at the transcriptional level by Akt activation. Akt phosphorylates FKHRL1 and inhibits its transcriptional activity, thus leading to the downregulation of p27 at the mRNA level (Medema et al., 2000). Akt phosphorylates another cell cycle inhibitor, p21, at two different residues Thr145 and Ser146. The Thr145 residue phosphorylation by Akt results in the cytoplasmic localization of p21 and thus promotes the cell cycle (Zhou et al., 2001), whereas the Ser 146 site phosphorylation enhances the stability of the protein and further increases the assembly of Cyclin D-CDK4 G1/S transition complex (Li et al., 2002). Recently, we observed the regulation of p21 at the transcription level by Akt in a FKHRL1-dependent manner (Maddika and Los, unpublished results). Although PI3-K/Akt pathway is mostly reported to be required for $G_{1} / S$ progression, there have been few studies suggesting a role for this pathway in $\mathrm{G}_{2} / \mathrm{M}$ progression, though the mechanisms are not completely understood (Shtivelman et al., 2002). Also, it was shown that Akt activation could overcome $\mathrm{a}_{2} / \mathrm{M}$ cell cycle checkpoint induced by DNA damage (Kandel et al., 2002).
Though PI3-K/Akt activity might be important for $\mathrm{G}_{2} / \mathrm{M}$ progression, it must be later transiently inactivated for mitotic exit, as the constitutive activation of this pathway leads to $\mathrm{G}_{2} / \mathrm{M}$ cell cycle arrest in an FKHRL1/Cyclin B/PLK dependent manner (Alvarez et al., 2001).

\subsection{Pro-cell death function of PI3-K/Akt pathway}

Although many studies support a positive role for the PI3-K/Akt pathway in promoting cell proliferation and cell survival, there are several exceptions where the PI3-K pathway is also involved in promoting cell death pathways. The activation of PI3-K/Akt has been shown to be required for the induction of apoptosis by selected apoptotic stimuli like CD95, cisplatin, arsenite, TNF, serum withdrawal, hypoxia in some defined experimental systems (Aki et al., 2001, 2003; Lee et al., 2005; Lu et al., 2006; Nimbalkar et al., 2003; Ono et al., 2004; Shack et al., 2003).

\section{Cyclins and cyclin-dependent kinases}

We have delineated in the introduction the role of cyclins, CDKs and their inhibitors for cell cycle progression. We will now discuss in greater detail the interactions of cyclins, CDKs and their natural and pharmacologic inhibitors, focusing on their role in cell cycle progression, apoptosis induction and cancerogenesis.

\subsection{Pro- and anti-apoptotic effects of cyclins}

In several kinds of malignant tumors, cyclins are overexpressed and hence rated as proto-oncogenes. For example, cyclin D was identified as an overexpressed gene in lung, breast, gastric and esophageal carcinomas at a relatively high frequency (Dobashi, 2005). Cyclin E, which has a vital role in $\mathrm{G}_{1} / \mathrm{S}$ phase transition, has been shown to be deregulated in some human cancers such as breast, gastrointestinal cancers and ovarian cancer (Dobashi, 2005). Cyclin A has been over expressed in several cultured cells including A549 adenocarinoma cells of the lung. Cyclin G overexpression promotes cell growth in RKO colon carcinoma cells. However, it has also been shown that retroviral expression of cyclin $G$ potentiates the TNF-induced apoptotic process in mouse fibroblast cells (Okamoto and Prives, 1999).

There are two mammalian A-type cyclins, namely cyclin A1 and A2. cyclin A1 is limited to male germ cells (Sweeney et al., 1996). Cyclin A1 null mice show cell cycle arrest and apoptosis of spermatocytes (Salazar et al., 2005). Apparently, Bax expression is elevated in cyclin A1 null mice's spermatocytes as compared to the normal mice leading to their apoptotic demise. This clearly shows that cyclin A1 plays a vital role in the regulation of apoptotic process by inhibiting the expression of Bax gene. Molecular mechanisms revealed that, apoptotic cell death is due to the cell cycle arrest in $\mathrm{G}_{2} / \mathrm{M}$ transition phase by downregulation of cyclin $\mathrm{A}$ and 
subsequent upregulation of proapoptotic $\mathrm{Bcl} 2$ family proteins (Palozza et al., 2002).

Recent investigations revealed that cyclin $\mathrm{E}$ is responsible for induction of apoptosis in hematopoietic cells (Mazumder et al., 2002). Cyclin E activity is increased substantially in the apoptotic process mediated by irradiation of RPMI 8226 cells. Overexpression of cyclin E by transient transfection did not directly induce apoptosis; however, such cells are sensitized to irradiation-induced apoptosis. Cyclin E usually exists as a 50-kDa protein (p50-cyclin E). During apoptosis it is cleaved into a $18-\mathrm{kDa}$ fragment (p18-cyclin $\mathrm{E}$ ) by caspases and it can no longer bind to the CDKs. Overexpression of $\mathrm{Bcl} 2$ protein downregulated the apoptotic process and at the same time reduced the expression of p18-cyclin E (Mazumder et al., 2002). These results throw some light on the roles of cyclin $\mathrm{E}$ in apoptosis. Unexpected evidence came from the experimental results of the same group, indicating that p18cyclin $\mathrm{E}$ interacts with the $\mathrm{Ku}-70$, a critical component in the non-homologous end-joining repair. It is speculated that interaction of cyclin $\mathrm{E}$ might inhibit the activity of $\mathrm{Ku}-70$ and hence augments the apoptotic process by inhibiting the DNA repair mechanism (Mazumder et al., 2004).

Cyclin D1 has been shown to induce apoptosis in variety of cancer cells such as NIH 3T3, mouse kidney and R070B cells (Kranenburg et al., 1996). Overexpression of cyclin D1 in the above cell lines has been shown to induce apoptosis by a p53-independent pathway. There is also a report that cyclin D1 induces apoptosis in rat fibroblast cell lines under serum-depleting conditions (Sofer-Levi and Resnitzky, 1996). Ectopic expression of cyclin D in the above studies caused apoptosis by deregulation of the $\mathrm{pRb} / \mathrm{E} 2 \mathrm{~F}$ pathway. Overexpression of cyclin D1 rendered pancreatic tumor cell lines less sensitive to cisplatin-induced apoptosis. Attenuation of cisplatin-induced apoptosis in cyclin D1 overexpressing cells was attributed to the upregulation of $\mathrm{Bcl} 2$ and Bcl-xL proteins. However, when the overexpressed Cyclin D1 was downregulated, using antisense RNA, the apoptotic cell death induced by cisplatin was enhanced (Biliran et al., 2005). Furthermore, cyclin D3 interacts with caspase-2, and this interaction lead to an increased caspase activity and apoptosis in HEK 293 cells (Mendelsohn et al., 2002). While over-expression of caspase-2 induced apoptosis in HEK 293 cells, co-expression of cyclin D3 and caspase- 2 potentiated the apoptotic process. Accordingly, co-expression of caspase2 mutants that does not interact with cyclin D3 does not increase apoptosis. These results clearly point out the fact that interaction of cyclin D3 and caspase-2 is required for the enhancement of apoptosis (Mendelsohn et al., 2002).

Cyclin B1 is an important regulator of apoptotic cell demise in many cell types. For example, in $\gamma$-radiationinduced apoptosis of hematopoietic cells, cyclin B1 was necessary to induce apoptosis (Porter et al., 2000) Moreover, downregulation of cyclin B1 by antisense RNA rescued cells from apoptosis (Porter et al., 2000). DNA damage-induced apoptosis was strongly dependent on the nuclear localization of cyclin B1 (Porter et al., 2003). This has been proven by ectopic expression of either cytoplasmic or nuclear cyclin B1. Apoptotic death was seen in the nuclear localizing cyclin B1 but not in cytoplasm localized cyclin B1 (Porter et al., 2003). In HeLa cells, cyclin B1 is expressed at high levels. Downregulation of cyclin B1 expression by siRNA lead to the anti-proliferative effects of the tumor cells. Interestingly, targeting of cyclin B1 by siRNA in primary human vascular endothelial cells (HUVECS), does not decrease their proliferation (Yuan et al., 2004). Camptothecin treatment of HT29 cells induced apoptosis (Banerji and Los, 2006; Borgne et al., 2006; Huang et al., 2006). This was accompanied by an increase in the expression of cyclin B1 and cyclin E2 in these cells. siRNA-mediated inhibition of cyclin B1 prevented the cells from undergoing apoptosis, whereas siRNA-targeting of cyclin E2 had no effect (Borgne et al., 2006). Thus, cyclin $\mathrm{B} 1$ expression is required for apoptotic induction by camptothecin in HT29 cells. The above data clearly implicates the dual role of cyclin B1 both in apoptosis and in cell proliferation.

Cyclin L2, a recently identified human cyclin, induces apoptosis in human hepatocellular carcinoma cell lines when overexpressed (Yang et al., 2004). Apoptosis mediated by cyclin L2 is due to the upregulation of p53 and Bax proteins, and downregulation of $\mathrm{Bcl} 2$ protein.

\section{Role of cyclin-depedent kinases in the regulation of cell cycle and apoptosis}

CDKs are a family of hetero-dimeric serine/threonine kinases that are essential for the progression of the cell cycle at every phase transition of the division process. In addition, they have distinct roles in regulating transcription and neuronal function. CDKs need to be complexed with their activating partners, cyclins, to exert their role on cell proliferation. CDKs, associated cyclins and CDK inhibitors act in a coordinated manner to achieve cellular homeostasis. Dysregulation of the CDKs and/or associated cyclins have been often found in tumors and neurodegenerative disorders. Hence, to develop effective therapeutic approaches targeting CDKs, it is essential to identify and understand their complete role in regulating two major cellular processes, cell division and apoptosis.

CDK1 is the only non-redundant member of the family of CDKs. It is involved in the $\mathrm{G}_{2} / \mathrm{M}$ transition and plays a vital role in mitosis. Inhibitors of CDK1 arrest the cell cycle at the $\mathrm{G}_{2} / \mathrm{M}$ transition (Gray et al., 1999). Screening a budding yeast proteomic library revealed that CDK1 exerts its effect on the cell cycle by phosphorylating a number of protein substrates that are involved in cell cycle regulation. So far, there have been no reports of viable $\mathrm{CDK} 1^{-/-}$mice, which suggests the critical role of CDK1 in cell proliferation. The tumor suppressor protein retinoblastoma $(\mathrm{Rb})$ is one of the major substrates for phosphorylation by CDK1 and CDK2.

CDK2 complexes with E-type and A-type cyclins. Initially, CDK2/cyclin E was thought to exclusively promote the $\mathrm{G}_{1} / \mathrm{S}$ transition; however, CDK2 knock-out mice are viable, 
though females and males remain infertile which suggests that CDK2 has a specific role in gametogenesis and meiosis while its role in cell proliferation can be compensated (Berthet et al., 2003; Ortega et al., 2003). This view is supported by the finding that $\mathrm{CDK} 1 /$ cyclin $\mathrm{E}$ complexes can compensate for the absence of CDK2 activity (Aleem et al., 2005; Kaldis and Aleem, 2005).

CDK1 activity following binding to its respective cyclins has been observed in cells that were committed to enter apoptosis after treatment with death inducing compounds like granzyme B (Shi et al., 1996), perforin, fragmentin2 and camptothecin (Borgne and Golsteyn, 2003; Shimizu et al., 1995). Moreover, exposure of tumor cells to CDK1 inhibitors for longer than $24 \mathrm{~h}$ can induce apoptosis (Vassilev et al., 2006). In non-cycling $G_{1}$ CD4+ CD8+ thymocytes, during exposure to apoptotic stimuli such as dexamethsone, heat-shock, $\gamma$-irradiation, or Fas/CD95 cross-linking, CDK2 activity was found to be increased indicating its role in thymocyte selection (Hakem et al., 1999).

\section{Effect of CDK inhibitors during cell cycle and apoptosis}

Cyclin-dependent kinases exert their cell cycle-regulatory functions by phosphorylating an array of substrates. The activity of these kinases can be limited by specific, endogenous or exogenous, cyclin dependent kinase inhibitors (CDKIs). There are two major families of endogenous CDKIs. The first family includes the INK4 (inhibitors of CDK4) proteins, which bind and inhibit CDK4 and CDK6 specifically during the $G_{1}$ phase. There are four such proteins: $\mathrm{p} 16^{\text {Ink } 4 \mathrm{a}}, \mathrm{p} 15^{\text {Ink } 4 \mathrm{~b}}, \mathrm{p} 18^{\text {Ink 4c }}, \mathrm{p} 19^{\text {Ink 4d }}$. These proteins prevent transition from $G_{1}$ to the $S$ phase by forming either an inactive ternary INK4-CDK4/6-cyclin D or binary INK4-CDK4/6 complex (Jeffrey et al., 2000). Unlike INK4 inhibitors, the Cip/Kip (CDK interacting protein/kinase inhibitory protein) family includes the inhibitory proteins, which bind and inactivate multiple cyclin $\mathrm{D}, \mathrm{E}$, $\mathrm{A} / \mathrm{CDK}$ complexes during all phases of the cell division cycle. This family contains three inhibitory proteins: p21 Cip1/Waf1, p27 ${ }^{\text {Kip1 }}$, p57 Kip2 (Sherr, 2001).

In addition to these endogenous CDKIs, there are few, small molecule inhibitors of CDKs: roscovitine/CYC202, olomoucine, flavopiridol and SU9516. These synthetic compounds can block or induce apoptosis depending on experimental conditions. The compounds reduce proliferation of tumors by stopping the cell cycle via inhibition of CDK1 and CDK2 (Wadler, 2001; Crews and Shotwell, 2003; Golsteyn, 2005).

\subsection{The INK4-family inhibitors}

The INK4 group of CDKIs is characterized by a narrow substrate specificity centered on CDK4 and CDK6. A member of this group, $\mathrm{p} 16^{\text {Ink } 4 \mathrm{a}}$ is encoded by $\mathrm{p} 16$ gene, a tumor suppressor, which opposes the activity of the cyclin D-dependent kinases. Its inhibitory effect is based on the ability to form complexes with CDK4/6 in order to prevent CDK4/6-cyclinD binding and $\mathrm{S}$ phase entry, respectively. Moreover, p16 $^{\text {Ink } 4 \mathrm{a}}$-mediated CDK4/6-cyclinD binding disruption cancels the $\mathrm{Rb}-\mathrm{E} 2 \mathrm{~F}$ mitogenic signal transduction and cells remain in $\mathrm{G}_{1}$ phase (Sherr, 2001). There is a tight linkage between $\mathrm{p} 16^{\mathrm{Ink}} 4 \mathrm{a}$ and $\mathrm{p} 14^{\mathrm{ARF}}$ protein. The ARF protein is encoded by an alternatively spliced variant of INK4a gene and inhibits cell cycle progression by stabilizing p53. This stabilization depends on the ability of ARF to create a complex with p53-MDM2 (mouse double minute 2; a small extra-chromosomal nuclear body) in order to prevent p53 from degradation by the proteasome. In addition, ARF is positively regulated by $\mathrm{E} 2 \mathrm{~F}$, a transcription factor induced by the $\mathrm{Rb}$, that activates the promoters of genes encoding for cyclin $\mathrm{E}$ and $\mathrm{A}$, which are crucial for $\mathrm{S}$ phase of the cell cycle. Furthermore, loss of $\mathrm{p} 16^{\text {Ink } 4 \mathrm{a}}$ is functionally equivalent to loss of $\mathrm{Rb}$ whereas loss of ARF amounts to loss of p53 (James and Peters, 2000; Sherr, 2001).

The second inhibitory protein from INK family, $\mathrm{p} 15^{\text {Ink } 4 \mathrm{~b}}$, regulates the cell cycle clock by inhibiting CDK4/6-cyclinD mediated phosphorylation of $\mathrm{Rb}$. Induction of $\mathrm{p} 15^{\text {Ink } 4 \mathrm{~b}}$ triggered $G_{1}$-phase arrest occurs in response to TGF- $\beta$ (Hannon and Beach, 1994; Reynisdottir et al., 1995). Loss of p15 gene is associated with lymphoproliferative disorders and tumor formation (Latres et al., 2000). The p15 $5^{\text {Ink } 4 \mathrm{~b}}$-mediated pathways that control $\mathrm{G}_{1} / \mathrm{S}$ transition are frequently deregulated in human cancers such as prostate cancer, melanoma, pituitary adenoma, acute myeloid leukemia, gastric cancer.

The other members of INK 4 class, p18 Ink $4 \mathrm{c}$ and p $19^{\text {Ink } 4 d}$ are expressed during fetal development and seem to play a key role in terminal differentiation (Phelps et al., 1998; Zindy et al., 1997). Expression of these inhibitors increases during $\mathrm{G}_{1} / \mathrm{S}$ transition, mimicking $\mathrm{G}_{1}$ arrest caused by pharmacologic CDKs inhibition (Hirai et al., 1995). The p18 $8^{\text {Ink } 4 c}$ inhibitor plays a key role in growth control consistent with the wide expression of the gene encoding for this protein in variety of tissues. It has been suggested that loss of p18 function results in shortening the $G_{1}$ phase and driving the cell cycle machinery. Furthermore, the p18 $8^{\text {Ink } 4 \mathrm{c}}$ acts synergistically with $\mathrm{p} 27^{\mathrm{Kip} 1}$ in mediating suppression of pituitary tumorigenesis. Mice lacking both p18 and p27 genes develop pituitary tumors almost as quickly as mice lacking the p18 gene alone (Franklin et al., 1998). Since loss of Rb gene leads to pituitary tumor (Hu et al., 1994), p18 $8^{\text {Ink } 4 \mathrm{c}}$ and p27 $7^{\mathrm{Kip} 1}$ are suspected to control the function of $\mathrm{Rb}$, which can be a common target for these two collaborating CDKIs. This suggests that two members of INK4 family are involved in growth suppression which is linked with the wild-type $\mathrm{Rb}$ function (Guan et al., 1994).

\subsection{Kip/Cip-family of CDK-inhibitors}

p2 $1^{\text {Cip1/Waf1 }}$ is a member of the Kip/Cip, a broad specificity class of CDKIs. This inhibitor was identified 
simultaneously by two independent research groups, and named as Waf1 (wild-type p53-activated fragment 1) and CDK-interacting protein 1 (Cip1). As the name indicates, the $\mathrm{p} 21^{\mathrm{Cip} 1 / \text { Waf } 1}$ is under the control of the p53 tumor suppressor, which drives faulty cells into apoptosis. The main role of $\mathrm{p} 21^{\mathrm{Cip} 1 / \mathrm{Waf} 1}$ in cell cycle regulation lies in its ability to inhibit the activity of cyclin A,E/CDK2 required for $G_{1} / S$ transition and therefore $G_{1}$ arrest.

Beyond the cell cycle, p21 Cip1/Waf1 can perform as a negative regulator of p53-dependent apoptosis. In DNA damaged cells, p21 ${ }^{\text {Cip1/Waf1 }}$ is responsible for p-53 dependent $\mathrm{G}_{1}$ arrest (Deng et al., 1995; Finlan and Hupp, 2005). After 48h, the expression of $\mathrm{p} 21^{\mathrm{Cip} 1 / \mathrm{Waf} 1}$ in cells treated with DNAdamaging agent decreased and the presence of a cleaved fragment of $\mathrm{p} 21^{\mathrm{Cip} 1 / \mathrm{Waf} 1}$ was observed. This event points at the cleavage of the cell cycle regulator protein $\mathrm{p} 21^{\mathrm{Cip} 1 / \mathrm{Waf} 1}$ during the terminal $\mathrm{G}_{1}$ arrest leading to apoptosis. The cleavage and inactivation of $\mathrm{p} 21^{\mathrm{Cip} 1 / \mathrm{Waf} 1}$ is mediated by caspase- 3 (Los et al., 2001). But $\mathrm{p} 21^{\mathrm{Cip} 1 / \mathrm{Waf} 1}$ may also act as apoptosis inhibitor. TGF- $\beta$, TNF, IFN- $\gamma$, and interleukin- 6 induce $\mathrm{p} 53$ independent expression of $\mathrm{p} 21^{\mathrm{Cip} 1 / \text { Waf } 1}$ and cause not only cell cycle inhibition but also suppress apoptosis. The probable mechanism of this action includes: (a) interaction with pro-apoptotic molecules such as pro-caspase-3, caspase- 8 or ASK-1 (apoptosis signal-regulating kinase 1); and (b) induction of $G_{1}$ arrest in response to binding to cyclin $A, E / C D K 2$ complexes (Gartel and Tyner, 2002).

The second member of Cip/Kip family of CDKIs, p27 Kip1 inhibits cyclinE/CDK2 and regulates $\mathrm{G}_{1} / \mathrm{S}$ transition. This inhibition occurs in cells arrested by TGF- $\beta$ or cell-cell contact. As mentioned before, $\mathrm{p} 27^{\mathrm{Kip} 1}$ plays an important role in pituitary tumor suppression by controlling the function of $\mathrm{Rb}$. The activity of $\mathrm{p} 27^{\mathrm{Kip} 1}$ is regulated by its fluctuations during the cell cycle. This means that the concentration of $\mathrm{p} 27^{\mathrm{Kip} 1}$ decreases in response to mitogen stimulation and increases when mitogens are withdrawn (Sherr, 1996). The degradation of $\mathrm{p} 27^{\mathrm{Kip} 1}$ mediated by interleukin-2 is required for cell cycle entry (Nourse et al., 1994). In addition, p $27^{\mathrm{Kip} 1}$ is reported to have an effect on apoptosis, suggesting its induction by overexpressed p $27^{\mathrm{Kip} 1}$ (Tenjo et al., 2000). In contrast, decreased expression of $\mathrm{p} 27^{\mathrm{Kip} 1}$ in tumor cells correlates with poor prognosis (Sherr, 1996).

The p57 Kip2, another member of the Kip/Cip family of CDKs inhibitors, plays a major role in embryonic development and its loss leads to developmental disorders (Yan et al., 1997). Reduction in expression of this inhibitor correlates with tumorigenesis in laryngeal mucosa, which can work as a good marker for diagnosis. The implication of p57 Kip2 in the control of cell cycle is not clear.

\section{3. “Small Molecule" CDK-inhibitors}

The inhibition of CDKs activity can also be achieved by small chemical compounds. The inhibitors such as: roscovitine/CYC202, flavopiridol, olomoucine, and SU9516 represent a group of very specific CDKs inhibitors which are able to stop the cell cycle by inhibiting CDK1 and 2 .

Another inhibitory compound, SU9516 exhibits a selective inhibition towards CDKs. Similarly to roscovitine and flavopiridol, SU9516 is involved in the induction of apoptosis. Furthermore, SU9516-mediated CDK2-inhibition entails a downturn in $\mathrm{Rb}$ protein phosphorylation required for CDK2/Cyclin complexes (Golsteyn, 2005).

The CDK inhibitors play a guarding/controlling role for the cell cycle machinery. They participate in crucial checkpoints within the cell cycle. Some of them act as tumor suppressors. All of the mentioned inhibitors aim at stopping the cell cycle by interaction with different CDKs and prevent the cell from faulty division. Disruption of individual checkpoints is a common event to all cancers. The pro-apoptotic role for CDKIs is still not well understood.

\section{Role of p53, E2F and Retinoblastoma protein in the control of apoptosis and cell cycle}

Many reviews discuss the role of $\mathrm{p} 53, \mathrm{Rb}$ and $\mathrm{E} 2 \mathrm{~F}$ in the regulation of cell proliferation and cell death; thus this paragraph aims only to highlight the most important facts about these proteins (Finlan and Hupp, 2005; Yu, 2006). It is considered that tumor suppressor genes have appeared during evolution probably to protect multicellular organisms from uncontrolled cellular division caused by arising mutations. This concept is supported by the fact that the corresponding proteins or pathways are mutated or inactivated in most human cancers.

Cell cycle control at the $\mathrm{G}_{0}-\mathrm{S}$ phase involves a complex interaction of various proteins. There are two major pathways involved in the cellular progression from $\mathrm{G}_{0}-\mathrm{S}$ phase: (a) $\mathrm{Rb}$ $\left(\mathrm{Rb}\right.$, cyclin $\mathrm{D} 1$, and $\left.\mathrm{p} 16^{\mathrm{INK} 4 \mathrm{~A}}\right)$ cell cycle pathway, and (b) p53/p21 Waf1 $\mathrm{G}_{1}-\mathrm{S}$ checkpoint arrest pathway. Despite both pathways acting largely independently, they share complex interaction patterns (Burke et al., 2005; Hsieh et al., 2002).

\section{1. p53-dependent cell cycle checkpoint machinery}

In response to stress stimuli, p53 which normally has a low expression level, accumulates within cells due to an increase in the protein's stability (Finlan and Hupp, 2005; Hsieh et al., 2002). Indeed, p53 integrates signals from various pathways that become activated as a result of different stimuli such as DNA damage, hypoxia, and oncogene activation. Under these conditions, p53 initiates various cellular responses that can lead to cell-cycle arrest, senescence, differentiation, DNA repair, apoptosis, and inhibition of angiogenesis (Finlan and Hupp, 2005; Giono and Manfredi, 2006). Most of these responses are carried out via its ability to function as a transcription factor. It $(a)$ mediates cell growth arrest by inducing the expression of p21, 14-3-3s, Cdc25C, and GADD45; (b) stimulates DNA repair by inducing the expression of $\mathrm{p} 21$, GADD45, and the p48 xeroderma pigmentosum protein; 


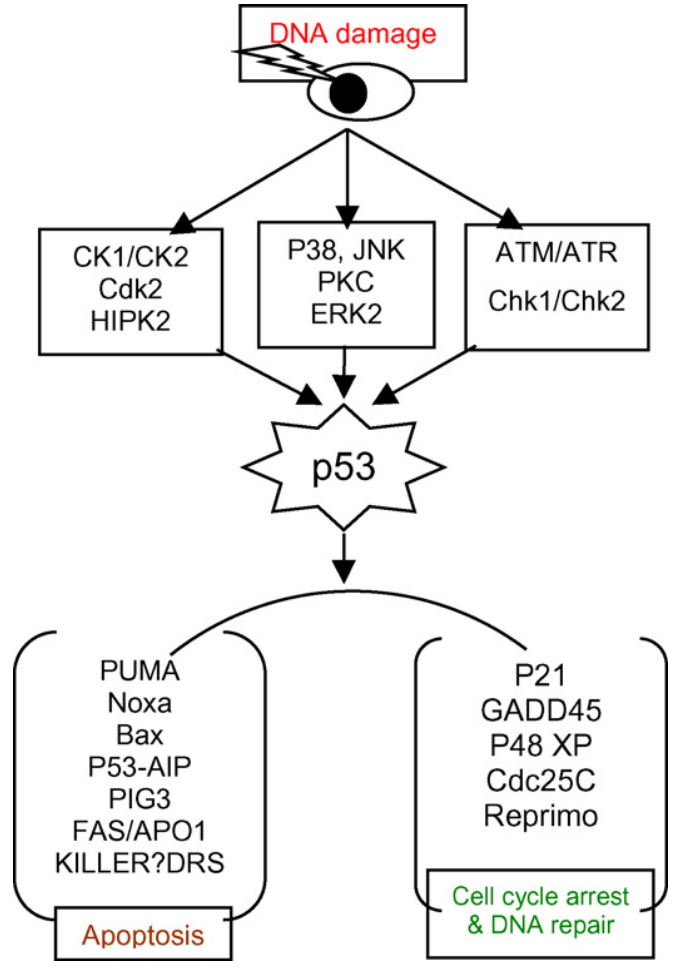

Fig. 1. Different pathways resulting from activation of $\mathrm{p} 53$ due to cell injury (see main text for details)

and $(c)$ induces apoptosis by upregulating the trancription of Bax, PUMA, Noxa, p53-AIP, PIG3, Fas/APO1/CD95, and KILLER/DR5 (Fig. 1). These responses are regulated through different mechanisms and are highly dependent on the type and amount of stimuli. For example, low levels of stress or DNA damage would induce levels of p53 that induces growth arrest genes. In contrast, under severe cellular stress, the higher levels of expressed and stabilized p53 activate apoptotic pathways. It has also been proposed that specific post-translational modifications of $\mathrm{p} 53$ are important for final outcome. Finally, it has been shown that p53 has a role in the apoptotic mitochondrial pathway which is largely independent from its transcriptional regulation (Mashima and Tsuruo, 2005; Giono and Manfredi, 2006). By inducing the expression of the CDKI p21 Waf1 in cells with damaged DNA, p53 prevents initiation of DNA replication in the $G_{1} / S$ checkpoint. p21 ${ }^{\text {Waf1 }}$ inhibits the phosphorylation of $\mathrm{Rb}$ (Finlan and Hupp, 2005; Giono and Manfredi, 2006). In addition, expression of $\mathrm{p} 21^{\text {Waf } 1}$ induces growth arrest at the $\mathrm{G}_{1}$ and $\mathrm{G}_{2}$ phases (Giono and Manfredi, 2006).

p53 may be predominantly involved in maintenance rather than initiation of either $G_{1}$ or $G_{2}$ arrests. It is shown that $\mathrm{G}_{1}$ arrest consists of two phases; the first is independent of p53, but the second is p53-dependent and involves the p53activating kinases ATM, ATR, and Chk2. Thus, it is proposed that $\mathrm{p} 53$-dependent arrest in $\mathrm{G}_{1}$ extends the delay initiated by $\mathrm{Cdc} 25 \mathrm{~A}$, providing the cell with sufficient time to repair the damaged DNA. During S phase, an isoform of p53 ( $\Delta \mathrm{p} 53)$ induces cell cycle arrest by binding to p21 Waf1 and 14-3- 3s growth arrest genes, but not the apoptotic PIG3 gene (Giono and Manfredi, 2006). p53 also prevents aneuploidy by blocking endoreduplication of tetraploid cells that result from mitotic failure (Giono and Manfredi, 2006). In addition to growth arrest and apoptosis, p53 is involved in regulating DNA repair after genotoxic stresses; p53 can directly interact with proteins involved in DNA repair and a variety of DNA structures. p53 binds to double-stranded and single-stranded DNA in a non-specific way, to ends of double-strand breaks, to Holliday junctions, and to DNA bulges caused by DNA mismatches (Giono and Manfredi, 2006).

\subsection{The retinoblastoma tumor suppressor gene}

$\mathrm{Rb}$ was the first tumor suppressor identified (Lee et al., 1987) and has a very significant role in controlling cell cycle. Besides tumor suppression, Rb is critical for stem cell maintenance, tissue regeneration, differentiation, and developmental programs. Rb protein is a 928 amino acid, nuclear phosphoprotein that possesses weak, nonspecific DNA binding activity. $\mathrm{Rb}$ protein reacts with a wide array of proteins that are mostly involved in transcription control. Among these proteins E2Fs are very important. E2F and its heterodimer partner, DP, are central regulators of cell cycle gene expression, and directly regulate the expression of genes involved in DNA replication, DNA repair, and $\mathrm{G}_{2} / \mathrm{M}$ progression (Knudsen and Knudsen, 2006).

$\mathrm{Rb}$ and its homologous family members, RBL1/p107 and RBL2/p130 mediate cell cycle arrest by antagonizing transcription factor E2F/DP. This is regulated in turn by the phosphorylation status of $\mathrm{Rb}$ family proteins. Only hypophosphorylated forms of the $\mathrm{Rb}$ protein family can interact with E2Fs during the cell cycle (Hsieh et al., 2002; Jackson and Pereira-Smith, 2006). Phosphorylation of Rb is catalyzed by the activity of CDK/cyclin complexes. In general, mitogenic signals (e.g. growth factors) lead to activation of CDK/cyclin complexes, while anti-mitogenic signaling pathways (e.g. as initiated by confluence or nutrient depletion) inhibit activation of the $G_{1} C D K /$ cyclins. Sufficient phosphorylation of $\mathrm{Rb}$ inactivates its transcriptional repressor function, thus allowing expression of E2F target genes, whose activity is essential for entry into $\mathrm{S}$ phase. $\mathrm{Rb}$ is held inactive (e.g. hyperphosphorylated) throughout the rest of the cell cycle ( $\mathrm{S}, \mathrm{G}_{2}$, and $\mathrm{M}$ phases) (Knudsen and Knudsen, 2006).

$\mathrm{Rb}$ family members also regulate gene expression by directing changes in chromatin structure. These chromatin changes can be implemented by recruiting histone deacetylases (HDACs), histone methyltransferases, SWI/SNF complex members, and, less well-characterized, DNA methyltransferases and polycomb proteins (Jackson and PereiraSmith, 2006). It has been shown that the integrity of the Rb pathway could influence the activity of p53 and vice versa (Hsieh et al., 2002).

Rb's function may be downregulated, or completely ablated by variety of mechanisms: (a) excessive expression of 
CDK4 or cyclin D which results in enhanced $\mathrm{Rb}$ phosphorylation, (b) loss or mutation of p16 ink4a $\mathrm{CDKI}$, (c) sequesteration by oncoproteins such as the human papilloma virus E7 protein, and finally (d) mutations of $\mathrm{Rb}$ gene (such as occuring in retinoblastoma) (Knudsen and Knudsen, 2006).

E2F/DP complexes are critical down-stream mediators of the $\mathrm{p}^{\mathrm{INK}} \mathrm{Ia}^{\mathrm{R}} / \mathrm{RB}$ pathway. Six different E2F-like proteins (E2F1, E2F2, E2F3, E2F4, E2F5, and E2F6) have been so far described. These complexes can be roughly classified into two subgroups: (a) activating E2Fs (E2F1, E2F2, and E2F3) are potent transcriptional activators and $(b)$ repressive E2Fs (E2F4, E2F5, and E2F6) that apparently repress transcription. Recent findings suggest that E2F/DP activity is essential for cell proliferation and its reduction immediately provokes a senescence-like cell cycle arrest (Maehara et al., 2005).

Overexpression of E2F1 can induce apoptosis independent of p53. There is also increasing evidence that in tumor cells E2F1 cooperates with p53 to induce apoptosis. This is independent of the transactivation function of E2F1, and may occur upon binding of E2F1 to p53 via its cyclin Adomain. Apparently, the level of cellular cyclin A determines this interaction. However, within normal cells and in the presence of $\mathrm{Rb}$, which down regulates E2F1, p53-stabilization induced by DNA damage cannot be activated to induce apoptosis by proteins like E2F. In addition, mitogen-induced E2F would transactivate genes like cyclin A, which prevents E2F binding to p53, thereby keeping cells alive. This could explain why in primary normal cells, a predominantly p53dependent $G_{1}$ arrest and not apoptosis occurs (Hsieh et al., 2002).

\section{Dual role of Myc family members in regulating cell cycle and apoptosis}

Twenty-five years have passed since c-Myc was discovered as the cellular homologue of the transduced oncogene of several avian retroviruses (Sheiness et al., 1978; Vennstrom et al., 1982). The gene encodes a transcription factor of the HLH/leucine zipper family of proteins that activates transcription as part of a heteromeric complex with a protein termed Max. Altogether, Myc family members function as regulators of gene transcription by heterodimerizing with Max through a network of Myc/Mad/Max proteins at the E-box element (Blackwell et al., 1990). Some of the biological functions of Myc family proteins are accomplished by sequence-specific DNA binding that is mediated by the carboxyl-terminal region of the protein (Blackwell et al., 1990) and a negative feedback mechanism can act as a homeostatic regulator of c-Myc expression in vivo (Penn et al., 1990). In mammalian fibroblasts, Myc acts as an upstream regulator of CDKs and functionally antagonizes the action of at least one CDKI, p27 (Steiner et al., 1996). In general, Myc is one of the few proteins that can solely drive resting cells into cell cycle and promote DNA synthesis. Interestingly, overexpression of Myc in these cells also blocks their differentiation. It is now well documented that translocations of c-Myc locus into the heavy or light chain immunoglobulin loci frequently occurs in Burkitt's lymphoma and amplification of N-Myc and L-Myc genes in neuroblastoma and small cell lung cancer, respectively (Heerema et al., 2005). Myc genes are among the most frequently affected genes in human cancers (Henriksson and Luscher, 1996).

Along with its transforming effect, Myc can also sensitizes the cells towards apoptosis, that indicates Myc is a part of the intracellular Life-and-Death switching system (Desbarats et al., 1996). In fact, the expression of Myc proteins is deregulated approximately in one third of human cancers by a number of different mechanisms (Spencer and Groudine, 1991). Likewise, overexpression of Myc is common in certain advanced cancers with poor prognosis such as colorectal cancers, hormone dependent breast and prostate cancers (Borg et al., 1992; Jenkins et al., 1997; Watson, 2006).

The effects of human c-Myc on cells' susceptibility to apoptosis were investigated by introducing them into immortalized rat fibroblasts, or by introduction of Myc that could be "on demand" activated by the addition of a small molecule (i.e. estrogen) (Alexander et al., 2007; Stroh et al., 2002). The transfected cells proliferated to a similar extent upon Myc activation or over expression, but differed by up to 15 -fold in the level of apoptosis, that correlated inversely with the expression of Myc. A necessary role of c-Myc was observed in apoptosis induced by $\mathrm{T}$-cell receptor activation and further studies also established that c-Myc is a critical determinant of apoptosis induced by TNF (Dong et al., 1997; Shi et al., 1992). However, it now appears that c-Myc is required for the efficient response to a variety of apoptotic stimuli, including transcription and translation inhibitors, heat shock, hypoxia, glucose deprivation, chemotherapeutic agents and DNA damage (Alarcon et al., 1996; Dong et al., 1997; Rupnow et al., 1998; Shim et al., 1998). It is also quite well documented that retroviral Myc proteins ( $\mathrm{v}-\mathrm{Myc}$ proteins) and other Myc family members like S-Myc, N-Myc and L-Myc have the capacity to induce apoptosis similar to c-Myc (Nesbit et al., 1998). The Myc-induced apoptotic program is counteracted by antiapoptotic Bcl2-family members (Bissonnette et al., 1992). The role of Bcl2-family members in cell cycle regulation and cell death is discussed to the greater detail in the next paragraph.

So far, several studies have revealed the regulatory circuits that link death receptors to c-Myc. Members of the TNF transmembrane receptor family, expressed on mesenchymal and epithelial cells use an adaptor system to activate the caspase directly (Los et al., 1995; Philchenkov et al., 2004). c-Myc sensitizes cells to death signals triggered by TNF receptors and CD95/Fas (Ashkenazi and Dixit, 1998).

Strong support has been established for the dual intrinsic function model of c-Myc as a coordinate activator of cell proliferation and apoptosis. These effector signals are hypothesized to include 'priming' and 'triggering' mechanisms associated with separable caspase-dependent 


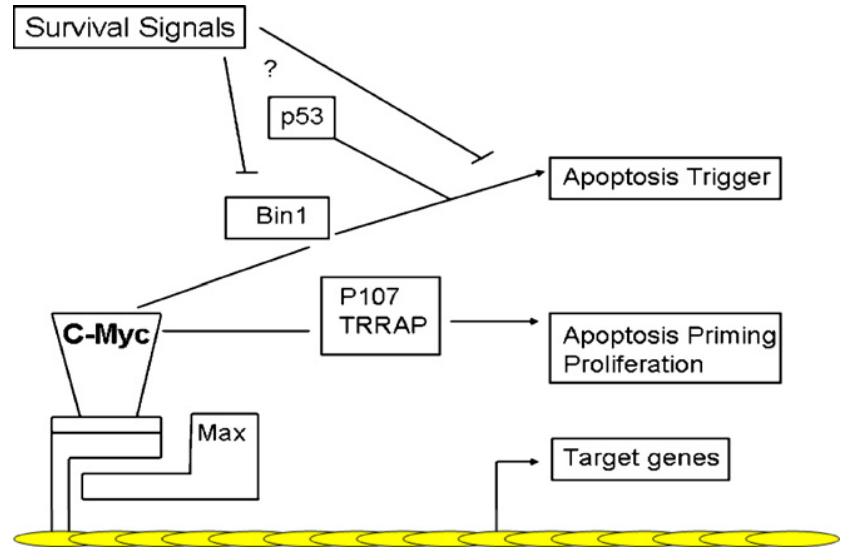

Fig. 2. A dual signal model for c-Myc function. The model proposes that c-Myc activates proliferation and primes apoptosis through one pathway and triggers apoptosis through a mechanistically distinct second pathway. In this model, death priming and proliferation involves regulation of specific target genes by c-Myc/Max complexes. The links between TRRAP and the transcription complex SAGA suggest possible involvements with the proliferation pathway. The interaction of p107 is proposed to co-ordinate the regulation of cell cycle-relevant genes. Max and gene regulation is required for proliferation and death priming but may be dispensable for death triggering. Conversely, Bin1 is dispensable for proliferation and death priming but necessary to trigger death once it is primed. p53 may contribute to sensitizing cells to the trigger, but is mechanistically distinct from Bin 1 since the latter can mediate p53-independent death. Survival signals from cytokine and adhesion receptor pathways are proposed to target the inactivation of triggering pathway (adapted with modifications from (Prendergast, 1999; Wechsler-Reya et al., 1997).

and caspase-independent process (Fig. 2) (Prendergast, 1999).

\section{The dual role of Bcl2-family members in cell cycle regulation and apoptosis}

Bcl2 family members are present in cells of all multicellular organisms and they play the key role in the regulation of mitochondria/apoptosome-dependent apoptosis. Proteins of the Bcl2 family can be further classified as either proapoptotic or anti-apoptotic and are characterized by distinct, evolutionarily conserved $\mathrm{Bcl} 2$ homology domains of which there are four (BH1-4). There are two types of pro-apoptotic Bcl2-family members. The majority of the pro-apoptotic Bcl2-family members are known as "BH3-only" molecules because they lack domains $\mathrm{BH} 1,-2$ and-4. Examples of BH3-only Bcl2 family members are Bad, Bid, Bim $\mathrm{EL}, \mathrm{Bmf}$, and $\mathrm{Mcl}_{\mathrm{S}}$. These molecules appear to be expressed in a tissue restricted manner. The smaller and more ubiquitously expressed group form multi-domain pro-apoptotic Bcl2-family members. Beside the $\mathrm{BH} 3$-domain these proteins also contain other domains typical to anti-apoptotic Bcl2-family members. That family contains Bax, Bok/Mtd, Bak, and Bcl-X . Oppositely, anti-apoptotic members contain at least a $\mathrm{BH} 1$ and $\mathrm{BH} 2$ domain (i.e. $\mathrm{Mcl}-1_{\mathrm{L}}$ ) or otherwise encompass all BH1-4 domains such as $\mathrm{Bcl} 2$ and $\mathrm{Bcl}-\mathrm{X}_{\mathrm{L}}$. Bio- chemical and physiological regulations of these two groups of proteins determine whether a cell survives or undergoes apoptosis (Lanave et al., 2004). Accumulating evidence suggests that some $\mathrm{Bcl} 2$ family members have dual roles, serving as molecular mediators of both apoptosis and cell cycle progression. It has recently been proposed that the dual functions of Bcl 2 family members in regulating apoptosis and cell cycle are primarily governed by the multi-domain members, whilst the role of BH3-only molecules are more variable (Zinkel et al., 2006).

The anti-apoptotic function of $\mathrm{Bcl} 2$ is characterized by mono- (Ser70) or multisite (Thr69, Ser70, and Ser87) phosphorylation in the flexible loop domain (FLD). Interestingly, $\mathrm{Bcl} 2$ phosphorylation has been shown to regulate intracellular reactive oxygen species (ROS) levels and subsequently inhibit cell cycle progression by delaying the $G_{1} / S$ transition (Deng et al., 2003). Bcl2 has also been shown to delay cell cycle entry by retarding the accumulation of E2F1, a critical inducer of cell cycle entry, and acting through mechanisms independent of Rb but dependent upon p130 and p27, all of which are negative regulators of the cell cycle (Vairo et al., 2000). Both $\mathrm{Bcl} 2$ and $\mathrm{Bcl}-\mathrm{X}_{\mathrm{L}}$ delay serum- and Myc-induced cell cycle entry via a mechanism involving the CDKI, p27, and $\mathrm{G}_{1} \mathrm{CDKs}$. Bcl- $\mathrm{X}_{\mathrm{L}}$ and $\mathrm{Bcl} 2$ elevate $\mathrm{p} 27$ levels thereby impeding the activation of CDK2 and CDK4 during progression to S-phase (Greider et al., 2002). In addition, Bcl- $\mathrm{X}_{\mathrm{L}}$ prolongs the $\mathrm{G}_{0}$ phase and enhances its arrest and induces a reduction in cell size and total RNA content during cell cycle arrest and entry, however this process has been shown to be reversible by Bad (Janumyan et al., 2003).

Pro-apoptotic Bad inhibits both cell cycle progression, and the anti-apoptotic functions of $\mathrm{Bcl}-\mathrm{X}_{\mathrm{L}}$ and $\mathrm{Bcl} 2$ via $\mathrm{BH} 3$ binding. Phosphorylation of Bad at Ser 128 by $\mathrm{Cdc} 2$ has been implicated to serve as a functional link between the role of Bad in regulating apoptosis and cell cycle. Cdc2-mediated phosphorylation at Ser136, and subsequent activation of Bad has been demonstrated to induce apoptosis in primary neuronal cells by inhibiting the interaction between Bad, and 14-3-3 (Konishi et al., 2002). Furthermore, Bad is regulated by reversible phosphorylation where dephosphorylation of Ser112, predominantly by protein phosphatase 2A (PP2A), is a prerequisite for dephosphorylation of pSer136, presumably by multiple phosphatases. Moreover, PP2A competes with 14-3-3 for Bad binding upon apoptosis induction by the withdrawal of survival factor interleukin-3 (IL-3), suggesting that PP2A is a positive regulator of Bad-mediated apoptosis (Chiang et al., 2003).

Other pro-apoptotic $\mathrm{Bcl} 2$ proteins including $\mathrm{Bax}$ and Bok/Mtd (Bcl2-related ovarian killer/Matador) have also been described to play a role in the unique coupling of apoptosis and cell cycle. The cell cycle arrest, and apoptosisinducing tumor suppressor $\mathrm{p} 53$, possesses the ability to mimic BH3-only molecules by catalyzing the liberation of Bcl- $\mathrm{X}_{\mathrm{L}}$ sequestered pro-apoptotic Bcl2 family members. Moreover, p53 facilitates direct activation of Bax thus inducing mitochondrial membrane permeabilization and apoptosis (Chipuk 
and Green, 2004). Bax has also been described to accelerate S-phase progression (Zinkel et al., 2006), although the underlying molecular processes are poorly understood. A recent study demonstrated that Bok/Mtd is cell cycle-regulated and can sensitize H1299 cells to anticancer chemotherapeuticsinduced apoptosis. It was shown that Bok mRNA is low in quiescent cells although it progressively increases with serum stimulation and that this process is dependent upon E2F1 over expression as it induces upregulation of Bok mRNA (Rodriguez et al., 2006).

\section{Conclusion and future directions}

As our understanding of cancer biology increases, so do the chances for the development of more effective and selective, targeted cancer therapies (Broxterman and Georgopapadakou, 2005). So far, much success has been achieved in the development of therapies that target malignancies associated with the overexpression of BCR-Abl (i.e. Gleevec), or a broad array of tumors that hyperactivated the EGFR/Her/Neu pathway (Booy et al., 2006; Brown and Gibson, 2005; Johnston et al., 2006; Krzemieniecki et al., 2006).

While cancer cells inactivate elements of apoptotic pathway, they never disable the entire signaling cascade, implying that at least some molecules share function between cell proliferation and cell death machinery. Accumulating knowledge on the functional significance of $\mathrm{Bcl} 2$ family members in linking apoptosis and the cell cycle continues to empower the pharmacological quest for therapeutic peptides and peptidomimetics in pathophysiological states such as cancer, acute liver damage, and ischemia of the myocardium and brain (Ghavami et al., 2005; Hauff et al., 2005; Huang, 2000; Kreuter et al., 2004; Mendoza et al., 2005). Many novel small molecule approaches integrating peptides or peptidomimetics are being constructed to mimic the proapoptotic function of the $\mathrm{BH} 3$ domain, a fundamental target model whose function, in excess, can overcome the molecular roadblocks impeding the success of conventional chemotherapy (Mendoza et al., 2005). Pharmacological optimization of BH3-peptides and derived mimics using "hydrocarbon stapling" to produce stable, protease-resistant $\alpha$-helices (Anderson et al., 2006; Kroczak et al., 2006; Walensky et al., 2004) or conjugation to cell penetrating peptides, such as the membrane translocation domain of the Antennapedia (Ant) protein to enhance membrane permeability (Hauff et al., 2005; Mendoza et al., 2005; Vieira et al., 2002), are proving to be efficacious methods in the design of potential drug candidates both in vitro and in vivo. The sophisticated dual role of the $\mathrm{Bcl} 2$ family members in the intricate regulation of apoptosis and the cell cycle makes them ideal therapeutic targets in diseases characterized by deregulated apoptotic pathways.

Since cell survival, cell death, and cell cycle progression pathways are interconnected, at least theoretically it should be possible to develop pharmacologically active substances that would "hijack" cell proliferation pathways and redirect them into apoptotic process. Several viral molecules like for example E4orf4, apoptin and VpR are able to selectively kill cancer cells (Maddika et al., 2005, 2006). Thus, they may harbor the potential, or even directly interact with key components of cell survival and proliferation pathways that are hyperactive in cancer cells, and redirect them towards the activation or amplification of the cell death machinery. Since cyclins play a dual role both as pro-apoptotic and anti-apoptotic proteins, at least theoretically it should be possible to selectively harness their pro-apoptotic potential and direct it towards selective activation of programmed cell death in cancer cells. Thus, understanding of the roles of these proteins will certainly pave a way towards more scientific advancement in the field of cancer biology and will provide solid foundations for the discovery of novel drug targets that would kill-, or at least control cancer progression.

Beside the outlined above specific approaches, researchers also try other non-conventional approaches in the battle with cancer, like for example, manipulation of the concentration of certain biologically important ions, or building blocks for DNA and/or RNA synthesis, or the utilization of naturally occurring proteins produced by the immune system (Frey and Brauer, 2006; Grote et al., 2006; Hashemi et al., 2005, 2007; Hashemi and Kroczak, 2005; Li et al., 2005). Most likely, the cure of cancer will be achieved by the combination of traditional approaches with selected targeting of cell cycle regulators and simultaneous sensitization to apoptosis. Likely, the rapidly accumulating knowledge of cancer immunology will aid us in either achieving of satisfactory level of remissions, or even in eliminating most of the cancer altogether by immunizations, as this is the case with the majority of morbid viral and many bacterial diseases.

\section{Acknowledgements}

M.L. thankfully acknowledges the support by the CFICanada Research Chair program, PCRFC-, CCMF-, MMSF MHRC, and CIHR-foundation-financed programs. S.M. thankfully acknowledges the support by the MHRC-, CCMFand by Univ. Manitoba funded fellowships. S.P., E.W., and K.W. thankfully acknowledge the support by CIHR-training fellowship. A.Z. S.P. and M.E. acknowledge the generous by CCMF-funded fellowships.

\section{References}

Aki, T., Mizukami, Y., Oka, Y., Yamaguchi, K., Uemura, K., Fujimiya, T., Yoshida, K., 2001. Phosphoinositide 3-kinase accelerates necrotic cell death during hypoxia. Biochem. J. 358, 481-487.

Aki, T., Yamaguchi, K., Fujimiya, T., Mizukami, Y., 2003. Phosphoinositide 3-kinase accelerates autophagic cell death during glucose deprivation in the rat cardiomyocyte-derived cell line H9c2. Oncogene 22, 85298535 
Alarcon, R.M., Rupnow, B.A., Graeber, T.G., Knox, S.J., Giaccia, A.J., 1996. Modulation of c-Myc activity and apoptosis in vivo. Cancer Res. 56, 4315-4319.

Aleem, E., Kiyokawa, H., Kaldis, P., 2005. Cdc2-cyclin E complexes regulate the G1/S phase transition. Nat. Cell Biol. 7, 831-836.

Alexander, H.C., Booy, E.P., Xiao, W., Baust, H., Ezzati, P., Los, M. Selected technologies to control genes and their products for experimental and clinical purposes. Arch. Immunol. Ther. Exp. 55, in press.

Ali, I.U., Schriml, L.M., Dean, M., 1999. Mutational spectra of PTEN/MMAC1 gene: a tumor suppressor with lipid phosphatase activity. J. Natl. Cancer Inst. 91, 1922-1932.

Alvarez, B., Martinez, A.C., Burgering, B.M., Carrera, A.C., 2001. Forkhead transcription factors contribute to execution of the mitotic programme in mammals. Nature 413, 744-747.

Anderson, J.E., Hansen, L.L., Mooren, F.C., Post, M., Hug, H., Zuse, A., Los, M., 2006. Methods and biomarkers for the diagnosis and prognosis of cancer and other diseases: towards personalized medicine. Drug Resist. Updates 9, 198-210.

Antonsson, B., Martinou, J.-C., 2000. The Bcl-2 protein family. Exp. Cell Res. 256, 50-57.

Ashkenazi, A., Dixit, V.M., 1998. Death receptors: signaling and modulation. Science 281, 1305-1308.

Banerji, S., Los, M., 2006. Important differences between topoisomerase-I and -II targeting agents. Cancer Biol. Ther. 5, 965-966.

Barczyk, K., Kreuter, M., Pryjma, J., Booy, E.P., Maddika, S., Ghavami, S., Berdel, W.E., Roth, J., Los, M., 2005. Serum cytochrome c indicates in vivo-apoptosis and it can serve as a prognostic marker during cancer therapy. Int. J. Cancer 114, 167-173.

Bernard, S., Eilers, M., 2006. Control of cell proliferation and growth by Myc proteins. Results Probl. Cell Differ. 42, 329-342.

Berthet, C., Aleem, E., Coppola, V., Tessarollo, L., Kaldis, P., 2003. Cdk2 knockout mice are viable. Curr. Biol. 13, 1775-1785.

Biliran Jr., H., Wang, Y., Banerjee, S., Xu, H., Heng, H., Thakur, A., Bollig, A., Sarkar, F.H., Liao, J.D., 2005. Overexpression of cyclin D1 promotes tumor cell growth and confers resistance to cisplatin-mediated apoptosis in an elastase-myc transgene-expressing pancreatic tumor cell line. Clin. Cancer Res. 11, 6075-6086.

Bissonnette, R.P., Echeverri, F., Mahboubi, A., Green, D.R., 1992. Apoptotic cell death induced by c-myc is inhibited by bcl-2. Nature $359,552-554$.

Blackwell, T.K., Kretzner, L., Blackwood, E.M., Eisenman, R.N., Weintraub, H., 1990. Sequence-specific DNA binding by the c-Myc protein. Science 250, 1149-1151.

Blagosklonny, M.V., Darzynkiewicz, Z., 2005. Strategies of protection of normal cells during chemo- and radiotherapy based on modulation of cell cycle and apoptotic pathways. In: Los, M., Gibson, S.B. (Eds.), Apoptotic Pathways as Target for Novel Therapies in Cancer and Other Diseases. Springer Science/Business Media Inc., New York, pp. 357391.

Booy, E.P., Johar, D., Maddika, S., Pirzada, H., Sahib, M.M., Gehrke, I., Loewen, S.D., Louis, S.D., Kadkhoda, K., Mowat, M., Los, M., 2006. Monoclonal and bispecific antibodies as novel therapeutics. Arch. Immunol. Ther. Exp. 54, 1-17.

Booy, E.P., Kadkhoda, K., Johar, D., Bay, G.H., Los, M., 2005. The immune system, involvement in neurodegenerative diseases, ageing and cancer. Curr. Med. Chem-Anti-Inflamm. Anti-Allergy Agents 4, 349353.

Borg, A., Baldetorp, B., Ferno, M., Olsson, H., Sigurdsson, H., 1992. cmyc amplification is an independent prognostic factor in postmenopausal breast cancer. Int. J. Cancer 51, 687-691.

Borgne, A., Golsteyn, R.M., 2003. The role of cyclin-dependent kinases in apoptosis. Prog. Cell Cycle Res. 5, 453-459.

Borgne, A., Versteege, I., Mahe, M., Studeny, A., Leonce, S., Naime, I., Rodriguez, M., Hickman, J.A., Meijer, L., Golsteyn, R.M., 2006. Analysis of cyclin B1 and CDK activity during apoptosis induced by camptothecin treatment. Oncogene 25, 7361-7372.

Brouckaert, G., Kalai, M., Saelens, X., Vandenabeele, P., 2005. Apoptotic Pathways and Their Regulation. In: Los, M., Gibson, S.B. (Eds.),
Apoptotic Pathways as Target for Novel Therapies in Cancer and Other Diseases. Springer Academic Press, New York.

Brown, J.G., Gibson, S.B., 2005. Growth factors, receptors, and kinases: their exploration to target cancer. In: Los, M., Gibson, S.B. (Eds.), Apoptotic Pathways as Target for Novel Therapies in Cancer and Other Diseases. Springer Academic Press.

Broxterman, H.J., Georgopapadakou, N.H., 2005. Anticancer therapeutics: addictive targets, multi-targeted drugs, new drug combinations. Drug Resist. Updates 8, 183-197.

Brunet, A., Bonni, A., Zigmond, M.J., Lin, M.Z., Juo, P., Hu, L.S., Anderson, M.J., Arden, K.C., Blenis, J., Greenberg, M.E., 1999. Akt promotes cell survival by phosphorylating and inhibiting a Forkhead transcription factor. Cell 96, 857-868.

Burke, L., Flieder, D.B., Guinee, D.G., Brambilla, E., Freedman, A.N., Bennett, W.P., Jones, R.T., Borkowski, A., Caporaso, N.A., Fleming, M., et al., 2005. Prognostic implications of molecular and immunohistochemical profiles of the $\mathrm{Rb}$ and $\mathrm{p} 53$ cell cycle regulatory pathways in primary non-small cell lung carcinoma. Clin. Cancer Res. 11, 232241.

Cantley, L.C., 2002. The phosphoinositide 3-kinase pathway. Science 296, 1655-1657.

Cardone, M.H., Roy, N., Stennicke, H.R., Salvesen, G.S., Franke, T.F., Stanbridge, E., Frisch, S., Reed, J.C., 1998. Regulation of cell death protease caspase- 9 by phosphorylation. Science $282,1318-1321$.

Carnero, A., Hannon, G.J., 1998. The INK4 family of CDK inhibitors. Curr. Top. Microbiol. Immunol. 227, 43-55.

Cassens, U., Lewinski, G., Samraj, A.K., von Bernuth, H., Baust, H., Khazaie, K., Los, M., 2003. Viral modulation of cell death by inhibition of caspases. Arch. Immunol. Ther. Exp. 51, 19-27.

Catz, S.D., Johnson, J.L., 2001. Transcriptional regulation of bcl-2 by nuclear factor kappa B and its significance in prostrate cancer. Oncogene 20, 7342-7351.

Chiang, C.W., Kanies, C., Kim, K.W., Fang, W.B., Parkhurst, C., Xie, M., Henry, T., Yang, E., 2003. Protein phosphatase 2A dephosphorylation of phosphoserine 112 plays the gatekeeper role for BAD-mediated apoptosis. Mol. Cell. Biol. 23, 6350-6362.

Chipuk, J.E., Green, D.R., 2004. Cytoplasmic p53: bax and forward. Cell Cycle 3, 429-431.

Collins, I., Garrett, M.D., 2005. Targeting the cell division cycle in cancer: CDK and cell cycle checkpoint kinase inhibitors. Curr. Opin. Pharmacol. 5, 366-373.

Coqueret, O., 2003. New targets for viral cyclins. Cell Cycle 2, 293-295.

Cory, S., Adams, J.M., 2002. The Bcl2 family: regulators of the cellular life-or-death switch. Nat. Rev. Cancer 2, 647-656.

Crews, C.M., Shotwell, J.B., 2003. Small-molecule inhibitors of the cell cycle: an overview. Prog. Cell Cycle Res. 5, 125-133.

Cuevas, B.D., Lu, Y., Mao, M., Zhang, J., LaPushin, R., Siminovitch, K., Mills, G.B., 2001. Tyrosine phosphorylation of p85 relieves its inhibitory activity on phosphatidylinositol 3-kinase. J. Biol. Chem. 276, 27455-27461.

Darzynkiewicz, Z., Juan, G., Li, X., Gorczyca, W., Murakami, T., Traganos, F., 1997. Cytometry in cell necrobiology: analysis of apoptosis and accidental cell death (necrosis). Cytometry 27, 1-20.

Datta, S.R., Dudek, H., Tao, X., Masters, S., Fu, H., Gotoh, Y., Greenberg, M.E., 1997. Akt phosphorylation of BAD couples survival signals to the cell-intrinsic death machinery. Cell 91, 231-241.

Deng, C., Zhang, P., Harper, J.W., Elledge, S.J., Leder, P., 1995. Mice lacking p21CIP1/WAF1 undergo normal development, but are defective in G1 checkpoint control. Cell 82, 675-684.

Deng, X., Gao, F., May Jr., W.S., 2003. Bcl2 retards G1/S cell cycle transition by regulating intracellular ROS. Blood 102, 3179-3185.

Desbarats, L., Schneider, A., Muller, D., Burgin, A., Eilers, M., 1996. Myc: a single gene controls both proliferation and apoptosis in mammalian cells. Experientia 52, 1123-1129.

Diehl, J.A., Cheng, M., Roussel, M.F., Sherr, C.J., 1998. Glycogen synthase kinase-3beta regulates cyclin D1 proteolysis and subcellular localization. Genes Dev. 12, 3499-3511. 
Dobashi, Y., 2005. Cell cycle regulation and its aberrations in human lung carcinoma. Pathol. Int. 55, 95-105.

Dong, J., Naito, M., Tsuruo, T., 1997. c-Myc plays a role in cellular susceptibility to death receptor-mediated and chemotherapy-induced apoptosis in human monocytic leukemia U937 cells. Oncogene 15, 639-647.

Finkel, E., 2001. The mitochondrian: is it central to apoptosis? Science 292, 624-626.

Finlan, L.E., Hupp, T.R., 2005. The life cycle of p53: a key target in drug development. In: Los, M., Gibson, S.B. (Eds.), Apoptotic Pathways as Target for Novel Therapies in Cancer and Other Diseases. Springer Academic Press, New York.

Franklin, D.S., Godfrey, V.L., Lee, H., Kovalev, G.I., Schoonhoven, R., Chen-Kiang, S., Su, L., Xiong, Y., 1998. CDK inhibitors p18(INK4c) and p27(Kip1) mediate two separate pathways to collaboratively suppress pituitary tumorigenesis. Genes Dev. 12, 2899-2911.

Frey, O., Brauer, R., 2006. Regulatory T cells: magic bullets for immunotherapy? Arch. Immunol. Ther. Exp. (Warsz) 54, 33-43.

Fruman, D.A., Meyers, R.E., Cantley, L.C., 1998. Phosphoinositide kinases. Annu. Rev. Biochem. 67, 481-507.

Gartel, A.L., 2005. The conflicting roles of the cdk inhibitor p21(CIP1/WAF1) in apoptosis. Leuk. Res. 29, 1237-1238.

Gartel, A.L., Tyner, A.L., 2002. The role of the cyclin-dependent kinase inhibitor p21 in apoptosis. Mol. Cancer Ther. 1, 639-649.

Ghavami, S., Hashemi, M., Kadkhoda, K., Alavian, S.M., Bay, G.H., Los, M., 2005. Apoptosis in liver diseases-detection and therapeutic applications. Med. Sci. Monit. 11, RA337-RA345.

Giono, L.E., Manfredi, J.J., 2006. The p53 tumor suppressor participates in multiple cell cycle checkpoints. J. Cell. Physiol. 209, 13-20.

Girard, F., Strausfeld, U., Fernandez, A., Lamb, N.J., 1991. Cyclin A is required for the onset of DNA replication in mammalian fibroblasts. Cell 67, 1169-1179.

Golsteyn, R.M., 2005. Cdk1 and Cdk2 complexes (cyclin dependent kinases) in apoptosis: a role beyond the cell cycle. Cancer Lett. 217, 129-138.

Gray, N., Detivaud, L., Doerig, C., Meijer, L., 1999. ATP-site directed inhibitors of cyclin-dependent kinases. Curr. Med. Chem. 6, 859-875.

Grant, S., Roberts, J.D., 2003. The use of cyclin-dependent kinase inhibitors alone or in combination with established cytotoxic drugs in cancer chemotherapy. Drug Resist. Updates 6, 15-26.

Gregory, M.A., Qi, Y., Hann, S.R., 2003. Phosphorylation by glycogen synthase kinase-3 controls c-myc proteolysis and subnuclear localization. J. Biol. Chem. 278, 51606-51612.

Greider, C., Chattopadhyay, A., Parkhurst, C., Yang, E., 2002. BCL-x(L) and BCL2 delay Myc-induced cell cycle entry through elevation of p27 and inhibition of G1 cyclin-dependent kinases. Oncogene 21, 77657775 .

Grote, J., Koenig, S., Ackermann, D., Sopalla, C., Benedyk, M., Los, M., Kerkhoff, C., 2006. Identification of poly(ADP-ribose)polymerase- 1 and $\mathrm{Ku} 70 / \mathrm{Ku} 80$ as transcriptional regulator of S100A9 gene expression. BMC Mol. Biol. 7, 48.

Guan, K.L., Jenkins, C.W., Li, Y., Nichols, M.A., Wu, X., O’Keefe, C.L., Matera, A.G., Xiong, Y., 1994. Growth suppression by p18, a p16INK4/MTS1- and p14INK4B/MTS2-related CDK6 inhibitor, correlates with wild-type pRb function. Genes Dev. 8, 2939-2952.

Guo, S., Rena, G., Cichy, S., He, X., Cohen, P., Unterman, T., 1999. Phosphorylation of serine 256 by protein kinase B disrupts transactivation by FKHR and mediates effects of insulin on insulin-like growth factorbinding protein-1 promoter activity through a conserved insulin response sequence. J. Biol. Chem. 274, 17184-17192.

Hakem, A., Sasaki, T., Kozieradzki, I., Penninger, J.M., 1999. The cyclindependent kinase Cdk2 regulates thymocyte apoptosis. J. Exp. Med. 189, 957-968.

Hannon, G.J., Beach, D., 1994. p15INK4B is a potential effector of TGFbeta-induced cell cycle arrest. Nature 371, 257-261.

Hara, T., Kamura, T., Nakayama, K., Oshikawa, K., Hatakeyama, S., Nakayama, K., 2001. Degradation of p27(Kip1) at the G(0)-G(1) transition mediated by a Skp2-independent ubiquitination pathway. J. Biol. Chem. 276, 48937-48943.
Hashemi, M., Ghavami, S., Eshraghi, M., Booy, E.P., Los, M., 2007. Cytotoxic effects of intra- and extracellular zinc chelation on human breast cancer cells. Eur. J. Pharm. 557, 9-19.

Hashemi, M., Karami-Tehrani, F., Ghavami, S., Maddika, S., Los, M., 2005. Adenosine and deoxyadenosine induces apoptosis in oestrogen receptorpositive and -negative human breast cancer cells via the intrinsic pathway. Cell Prolif. 38, 269-285.

Hashemi, M., Kroczak, T.J., 2005. Apoptosis and Autoimmune Disease. Curr. Med. Chem.-Anti-Inflamm. Anti-Allergy Agents 4, 429-438.

Hauff, K., Zamzow, C., Law, W.J., de Melo, J., Kennedy, K., Los, M., 2005. Peptide-based approaches to treat asthma, arthritis, other autoimmune diseases and pathologies of the central nervous system. Arch. Immunol. Ther. Exp. 53, 308-320.

Heerema, N.A., Bernheim, A., Lim, M.S., Look, A.T., Pasqualucci, L., Raetz, E., Sanger, W.G., Cairo, M.S., 2005. State of the Art and Future Needs in Cytogenetic/Molecular Genetics/Arrays in Childhood Lymphoma: Summary Report of Workshop at the First International Symposium on Childhood and Adolescent Non-Hodgkin Lymphoma, April 9, 2003, New York City. NY. Ped. Blood Cancer 45, 616-622.

Hengartner, M.O., 2000. The biochemistry of apoptosis. Nature 407, 770-776.

Hengst, L., Reed, S.I., 1998. Inhibitors of the Cip/Kip family. Curr. Top. Microbiol. Immunol. 227, 25-41.

Henriksson, M., Luscher, B., 1996. Proteins of the Myc network: essential regulators of cell growth and differentiation. Adv. Cancer Res. 68, $109-182$.

Hinds, P.W., Dowdy, S.F., Eaton, E.N., Arnold, A., Weinberg, R.A., 1994. Function of a human cyclin gene as an oncogene. Proc. Natl. Acad. Sci. U.S.A. 91, 709-713.

Hirai, H., Roussel, M.F., Kato, J.Y., Ashmun, R.A., Sherr, C.J., 1995. Novel INK4 proteins, p19 and p18, are specific inhibitors of the cyclin Ddependent kinases CDK4 and CDK6. Mol. Cell Biol. 15, 2672-2681.

Hiromura, K., Pippin, J.W., Fero, M.L., Roberts, J.M., Shankland, S.J., 1999. Modulation of apoptosis by the cyclin-dependent kinase inhibitor p27(Kip1). J. Clin. Invest. 103, 597-604.

Hoang, A.T., Cohen, K.J., Barrett, J.F., Bergstrom, D.A., Dang, C.V., 1994. Participation of cyclin A in Myc-induced apoptosis. Proc. Natl. Acad. Sci. U.S.A. 91, 6875-6879.

Hsieh, J.K., Yap, D., O’Connor, D.J., Fogal, V., Fallis, L., Chan, F., Zhong, S., Lu, X., 2002. Novel function of the cyclin A binding site of E2F in regulating p53-induced apoptosis in response to DNA damage. Mol. Cell Biol. 22, 78-93.

Hu, N., Gutsmann, A., Herbert, D.C., Bradley, A., Lee, W.H., Lee, E.Y., 1994. Heterozygous Rb-1 delta 20/+mice are predisposed to tumors of the pituitary gland with a nearly complete penetrance. Oncogene 9, 1021-1027.

Huang, X., Kurose, A., Tanaka, T., Traganos, F., Dai, W., Darzynkiewicz, Z., 2006. Activation of ATM and histone H2AX phosphorylation induced by mitoxantrone but not by topotecan is prevented by the antioxidant N-acetyl-L-cysteine. Cancer Biol. Ther. 5, 959-964.

Huang, Z., 2000. Bcl-2 family proteins as targets for anticancer drug design. Oncogene 19, 6627-6631.

Hunter, T., Pines, J., 1991. Cyclins and cancer. Cell 66, 1071-1074.

Ivanchuk, S.M., Mondal, S., Dirks, P.B., Rutka, J.T., 2001. The INK4A/ARF locus: role in cell cycle control and apoptosis and implications for glioma growth. J. Neurooncol. 51, 219-229.

Jackson, J.G., Pereira-Smith, O.M., 2006. Primary and compensatory roles for RB family members at cell cycle gene promoters that are deacetylated and downregulated in doxorubicin-induced senescence of breast cancer cells. Mol. Cell. Biol. 26, 2501-2510.

James, M.C., Peters, G., 2000. Alternative product of the p16/CKDN2A locus connects the Rb and 553 tumor suppressors. Prog. Cell Cycle Res. 4, 71-81.

Janumyan, Y.M., Sansam, C.G., Chattopadhyay, A., Cheng, N., Soucie, E.L., Penn, L.Z., Andrews, D., Knudson, C.M., Yang, E., 2003. Bcl-xL/Bcl-2 coordinately regulates apoptosis, cell cycle arrest and cell cycle entry. EMBO J. 22, 5459-5470. 
Jeffrey, P.D., Tong, L., Pavletich, N.P., 2000. Structural basis of inhibition of CDK-cyclin complexes by INK4 inhibitors. Genes Dev. 14, 3115-3125.

Jenkins, R.B., Qian, J., Lieber, M.M., Bostwick, D.G., 1997. Detection of cmyc oncogene amplification and chromosomal anomalies in metastatic prostatic carcinoma by fluorescence in situ hybridization. Cancer Res. $57,524-531$.

Johnson, D.G., Walker, C.L., 1999. Cyclins and cell cycle checkpoints. Annu. Rev. Pharmacol. Toxicol. 39, 295-312.

Johnston, J.B., Navaratnam, S., Pitz, M.W., Maniate, J.M., Wiechec, E., Baust, H., Gingerich, J., Skliris, G.P., Murphy, L.C., Los, M., 2006. Targeting the EGFR pathway for cancer therapy. Curr. Med. Chem. 13, 3483-3492.

Jones, S.M., Klinghoffer, R., Prestwich, G.D., Toker, A., Kazlauskas, A., 1999. PDGF induces an early and a late wave of PI 3-kinase activity, and only the late wave is required for progression through G1. Curr. Biol. 9, 512-521.

Kaldis, P., Aleem, E., 2005. Cell cycle sibling rivalry: Cdc2 vs. Cdk2. Cell Cycle 4, 1491-1494.

Kandel, E.S., Skeen, J., Majewski, N., Di Cristofano, A., Pandolfi, P.P., Feliciano, C.S., Gartel, A., Hay, N., 2002. Activation of Akt/protein kinase B overcomes a $\mathrm{G}(2) / \mathrm{m}$ cell cycle checkpoint induced by DNA damage. Mol. Cell. Biol. 22, 7831-7841.

Kane, L.P., Shapiro, V., Stokoe, D., Weiss, A., 1999. Induction of NF-kappaB by the Akt/PKB kinase. Curr. Biol. 9, 601-604.

Khosravi-Far, R., Esposti, M.D., 2004. Death receptor signals to mitochondria. Cancer Biol. Ther. 3, 1051-1057.

Kim, R., Emi, M., Tanabe, M., 2006. Role of mitochondria as the gardens of cell death. Cancer Chemother. Pharmacol. 57, 545-553.

Knudsen, E.S., Knudsen, K.E., 2006. Retinoblastoma tumor suppressor: where cancer meets the cell cycle. Exp. Biol. Med. (Maywood) 231, 1271-1281.

Koff, A., Cross, F., Fisher, A., Schumacher, J., Leguellec, K., Philippe, M., Roberts, J.M., 1991. Human cyclin E, a new cyclin that interacts with two members of the CDC2 gene family. Cell 66, 1217-1228.

Konishi, Y., Lehtinen, M., Donovan, N., Bonni, A., 2002. Cdc2 phosphorylation of BAD links the cell cycle to the cell death machinery. Mol. Cell 9, 1005-1016.

Kops, G.J., de Ruiter, N.D., De Vries-Smits, A.M., Powell, D.R., Bos, J.L., Burgering, B.M., 1999. Direct control of the Forkhead transcription factor AFX by protein kinase B. Nature 398, 630-634.

Kranenburg, O., van der Eb, A.J., Zantema, A., 1996. Cyclin D1 is an essential mediator of apoptotic neuronal cell death. EMBO J. 15, 4654.

Kreuter, M., Langer, C., Kerkhoff, C., Reddanna, P., Kania, A.L., Maddika, S., Chlichlia, K., Bui, T.N., Los, M., 2004. Stroke, myocardial infarction, acute and chronic inflammatory diseases: caspases and other apoptotic molecules as targets for drug development. Arch. Immunol. Ther. Exp. $52,141-155$.

Kroczak, T.J., Baran, J., Pryjma, J., Siedlar, M., Rashedi, I., Hernandez, E., Alberti, E., Maddkia, S., Los, M., 2006. The emerging importance of DNA mapping and other comprehensive screening techniques as tools to identify new drug targets and as a mean of (cancer) therapy personalization. Expert Opin. Ther. Targets 10, 289-302.

Krzemieniecki, K., Szpyt, E., Rashedi, I., Gawron, K., Los, M., 2006. Targeting of solid tumors and blood malignancies by antibody-based therapies. Central Eur. J. Biol. 1, 167-182.

Lanave, C., Santamaria, M., Saccone, C., 2004. Comparative genomics: the evolutionary history of the Bcl-2 family. Gene 333, 71-79.

Latres, E., Malumbres, M., Sotillo, R., Martin, J., Ortega, S., MartinCaballero, J., Flores, J.M., Cordon-Cardo, C., Barbacid, M., 2000. Limited overlapping roles of P15(INK4b) and P18(INK4c) cell cycle inhibitors in proliferation and tumorigenesis. EMBO J. 19, 34963506.

Lee, H.H., Dadgostar, H., Cheng, Q., Shu, J., Cheng, G., 1999. NF-kappaBmediated up-regulation of Bcl-x and Bfl-1/A1 is required for CD40 survival signaling in B lymphocytes. Proc. Natl. Acad. Sci. U.S.A. 96, 9136-9141.
Lee, S.B., Cho, E.S., Yang, H.S., Kim, H., Um, H.D., 2005. Serum withdrawal kills U937 cells by inducing a positive mutual interaction between reactive oxygen species and phosphoinositide 3-kinase. Cell Signal 17, 197-204.

Lee, W.H., Bookstein, R., Hong, F., Young, L.J., Shew, J.Y., Lee, E.Y., 1987. Human retinoblastoma susceptibility gene: cloning, identification, and sequence. Science 235, 1394-1399.

Li, X., Zhang, Z., Beiter, T., Schluesener, H.J., 2005. Nanovesicular vaccines: exosomes. Arch. Immunol. Ther. Exp. (Warsz) 53, 329-335.

Li, Y., Dowbenko, D., Lasky, L.A., 2002. AKT/PKB phosphorylation of $\mathrm{p} 21 \mathrm{Cip} / \mathrm{WAF} 1$ enhances protein stability of $\mathrm{p} 2 \mathrm{Cip} / \mathrm{WAF} 1$ and promotes cell survival. J. Biol. Chem. 277, 11352-11361.

Liang, J., Slingerland, J.M., 2003. Multiple roles of the PI3K/PKB (Akt) pathway in cell cycle progression. Cell Cycle 2, 339-345.

Loeffler, M., Kroemer, G., 2000. The mitochondrion in cell death control: certainties and incognita. Exp. Cell Res. 256, 19-26.

Los, M., Gibson, S., 2005. Apoptotic Pathways as Target for Novel Therapies of Cancer and Other Diseases. Springer, New York.

Los, M., Stroh, C., Janicke, R.U., Engels, I.H., Schulze Osthoff, K., 2001. Caspases: more than just killers? Trends Immunol. 22, 31-34.

Los, M., van de Craen, M., Penning, C.L., Schenk, H., Westendorp, M., Baeuerle, P.A., Dröge, W., Krammer, P.H., Fiers, W., Schulze-Osthoff, K., 1995. Requirement of an ICE/Ced-3 protease for Fas/Apo-11 mediated apoptosis. Nature $371,81-83$.

Los, M., Wesselborg, S., Schulze-Osthoff, K., 1999. The role of caspases in development, immunity, and apoptotic signal transduction: lessons from knockout mice. Immunity 10, 629-639.

Lu, B., Wang, L., Stehlik, C., Medan, D., Huang, C., Hu, S., Chen, F., Shi, X., Rojanasakul, Y., 2006. Phosphatidylinositol 3-kinase/Akt positively regulates Fas (CD95)-mediated apoptosis in epidermal Cl41 cells. J. Immunol. 176, 6785-6793.

Maddika, S., Booy, E.P., Johar, D., Gibson, S.B., Ghavami, S., Los, M., 2005. Cancer-specific toxicity of apoptin is independent of death receptors but involves the loss of mitochondrial membrane potential and the release of mitochondrial cell death mediators by a Nur77-dependent pathway. J. Cell Sci. 118, 4485-4493.

Maddika, S., Mendoza, F.J., Hauff, K., Zamzow, C.R., Paranjothy, T., Los, M., 2006. Cancer-selective therapy of the future: apoptin and its mechanism of action. Cancer Biol. Ther. 5, 10-19.

Maehara, K., Yamakoshi, K., Ohtani, N., Kubo, Y., Takahashi, A., Arase, S., Jones, N., Hara, E., 2005. Reduction of total E2F/DP activity induces senescence-like cell cycle arrest in cancer cells lacking functional pRB and p53. J. Cell Biol. 168, 553-560.

Mamillapalli, R., Gavrilova, N., Mihaylova, V.T., Tsvetkov, L.M., Wu, H., Zhang, H., Sun, H., 2001. PTEN regulates the ubiquitin-dependent degradation of the CDK inhibitor p27(KIP1) through the ubiquitin E3 ligase SCF(SKP2). Curr. Biol. 11, 263-267.

Marte, B.M., Downward, J., 1997. PKB/Akt: connecting phosphoinositide 3-kinase to cell survival and beyond. Trends Biochem. Sci. 22, 355-358.

Mashima, T., Tsuruo, T., 2005. Defects of the apoptotic pathway as therapeutic target against cancer. Drug Resist. Updates 8, 339-343.

Mayo, L.D., Donner, D.B., 2001. A phosphatidylinositol 3-kinase/Akt pathway promotes translocation of $\mathrm{Mdm} 2$ from the cytoplasm to the nucleus. Proc. Natl. Acad. Sci. U.S.A. 98, 11598-11603.

Mazumder, S., DuPree, E.L., Almasan, A., 2004. A dual role of cyclin E in cell proliferation and apoptosis may provide a target for cancer therapy. Curr. Cancer Drug Targets 4, 65-75.

Mazumder, S., Gong, B., Chen, Q., Drazba, J.A., Buchsbaum, J.C., Almasan, A., 2002. Proteolytic cleavage of cyclin $\mathrm{E}$ leads to inactivation of associated kinase activity and amplification of apoptosis in hematopoietic cells. Mol. Cell. Biol. 22, 2398-2409.

Medema, R.H., Kops, G.J., Bos, J.L., Burgering, B.M., 2000. AFX-like Forkhead transcription factors mediate cell-cycle regulation by Ras and PKB through p27kip1. Nature 404, 782-787.

Meikrantz, W., Gisselbrecht, S., Tam, S.W., Schlegel, R., 1994. Activation of cyclin A-dependent protein kinases during apoptosis. Proc. Natl. Acad. Sci. U.S.A. 91, 3754-3758. 
Mendelsohn, A.R., Hamer, J.D., Wang, Z.B., Brent, R., 2002. Cyclin D3 activates Caspase 2, connecting cell proliferation with cell death. Proc. Natl. Acad. Sci. U.S.A. 99, 6871-6876.

Mendoza, F.J., Espino, P.S., Cann, K.L., Bristow, N., McCrea, K., Los, M., 2005. Anti-tumor chemotherapy utilizing peptide-based approachesapoptotic pathways, kinases, and proteasome as targets. Arch. Immunol. Ther. Exp. 53, 47-60.

Morgan, D.O., 1997. Cyclin-dependent kinases: engines, clocks, and microprocessors. Annu. Rev. Cell. Dev. Biol. 13, 261-291.

Nesbit, C.E., Grove, L.E., Yin, X., Prochownik, E.V., 1998. Differential apoptotic behaviors of c-myc, N-myc, and L-myc oncoproteins. Cell Growth Differ. 9, 731-741.

Nimbalkar, D., Henry, M.K., Quelle, F.W., 2003. Cytokine activation of phosphoinositide 3-kinase sensitizes hematopoietic cells to cisplatininduced death. Cancer Res. 63, 1034-1039.

Nourse, J., Firpo, E., Flanagan, W.M., Coats, S., Polyak, K., Lee, M.H., Massague, J., Crabtree, G.R., Roberts, J.M., 1994. Interleukin-2-mediated elimination of the $\mathrm{p} 27 \mathrm{Kip} 1$ cyclin-dependent kinase inhibitor prevented by rapamycin. Nature $372,570-573$.

Okada, H., Mak, T.W., 2004. Pathways of apoptotic and non-apoptotic death in tumour cells. Nat. Rev. Cancer 4, 592-603.

Okamoto, K., Prives, C., 1999. A role of cyclin G in the process of apoptosis. Oncogene 18, 4606-4615.

Oliver, L., Vallette, F.M., 2005. The role of caspases in cell death and differentiation. Drug Resist. Updates 8, 163-170.

Ono, K., Iwanaga, Y., Hirayama, M., Kawamura, T., Sowa, N., Hasegawa, K., 2004. Contribution of caveolin-1 alpha and Akt to TNF-alphainduced cell death. Am. J. Physiol. Lung Cell. Mol. Physiol. 287, L201L209.

Ortega, S., Prieto, I., Odajima, J., Martin, A., Dubus, P., Sotillo, R., Barbero, J.L., Malumbres, M., Barbacid, M., 2003. Cyclin-dependent kinase 2 is essential for meiosis but not for mitotic cell division in mice. Nat. Genet. 35, 25-31.

Pagano, M., Tam, S.W., Theodoras, A.M., Beer-Romero, P., Del Sal, G., Chau, V., Yew, P.R., Draetta, G.F., Rolfe, M., 1995. Role of the ubiquitinproteasome pathway in regulating abundance of the cyclin-dependent kinase inhibitor p27. Science 269, 682-685.

Palozza, P., Serini, S., Maggiano, N., Angelini, M., Boninsegna, A., Di Nicuolo, F., Ranelletti, F.O., Calviello, G., 2002. Induction of cell cycle arrest and apoptosis in human colon adenocarcinoma cell lines by betacarotene through down-regulation of cyclin $\mathrm{A}$ and $\mathrm{Bcl}-2$ family proteins. Carcinogenesis 23, 11-18.

Panigrahi, S., Mai, S., 2005. Telomeres, genomic instability, DNA repair and breast cancer. Curr. Med. Chem. Anti-Inflamm. Anti-Allergy Agents 4, 421-428.

Park, M.-T., Lee, S.-J., 2003. Celll cycle and cancer. J. Biochem. Mol. Biol. $23,60-65$.

Penn, L.J., Brooks, M.W., Laufer, E.M., Land, H., 1990. Negative autoregulation of c-myc transcription. EMBO J. 9, 1113-1121.

Phelps, D.E., Hsiao, K.M., Li, Y., Hu, N., Franklin, D.S., Westphal, E., Lee, E.Y., Xiong, Y., 1998. Coupled transcriptional and translational control of cyclin-dependent kinase inhibitor p18INK4c expression during myogenesis. Mol. Cell. Biol. 18, 2334-2343.

Philchenkov, A., Zavelevich, M., Kroczak, T.J., Los, M., 2004. Caspases and cancer: mechanisms of inactivation and new treatment modalities. Exp. Oncol. 26, 82-97.

Pines, J., Hunter, T., 1989. Isolation of a human cyclin cDNA: evidence for cyclin mRNA and protein regulation in the cell cycle and for interaction with p34cdc2. Cell 58, 833-846.

Porter, L.A., Cukier, I.H., Lee, J.M., 2003. Nuclear localization of cyclin B1 regulates DNA damage-induced apoptosis. Blood 101, 1928-1933.

Porter, L.A., Singh, G., Lee, J.M., 2000. Abundance of cyclin B1 regulates gamma-radiation-induced apoptosis. Blood 95, 2645-2650.

Prendergast, G.C., 1999. Mechanisms of apoptosis by c-Myc. Oncogene 18, 2967-2987.

Pugazhenthi, S., Nesterova, A., Sable, C., Heidenreich, K.A., Boxer, L.M., Heasley, L.E., Reusch, J.E., 2000. Akt/protein kinase B up-regulates Bcl-
2 expression through cAMP-response element-binding protein. J. Biol. Chem. 275, 10761-10766.

Reed, J.C., 1997. Bcl-2 family proteins: regulators of apoptosis and chemoresistance in hematologic malignancies. Semin Hematol. 34 (Suppl 5), 9-19.

Reusch, J.E., Klemm, D.J., 2002. Inhibition of cAMP-response elementbinding protein activity decreases protein kinase B/Akt expression in 3T3-L1 adipocytes and induces apoptosis. J. Biol. Chem. 277, 1426-1432.

Reynisdottir, I., Polyak, K., Iavarone, A., Massague, J., 1995. Kip/Cip and Ink4 Cdk inhibitors cooperate to induce cell cycle arrest in response to TGF-beta. Genes Dev. 9, 1831-1845.

Rodriguez, J.M., Glozak, M.A., Ma, Y., Cress, W.D., 2006. Bok, Bcl-2related Ovarian Killer, Is cell cycle-regulated and sensitizes to stressinduced apoptosis. J. Biol. Chem. 281, 22729-22735.

Romashkova, J.A., Makarov, S.S., 1999. NF-kappaB is a target of AKT in anti-apoptotic PDGF signalling. Nature 401, 86-90.

Rowinsky, E.K., 2005. Targeted induction of apoptosis in cancer managment: the emerging role of tumor necrosis factor-related apoptosis-inducing ligand receptor activating agents. J. Clin. Oncol. 23, 9394-9405.

Rupnow, B.A., Murtha, A.D., Alarcon, R.M., Giaccia, A.J., Knox, S.J., 1998. Direct evidence that apoptosis enhances tumor responses to fractionated radiotherapy. Cancer Res. 58, 1779-1784.

Salazar, G., Joshi, A., Liu, D., Wei, H., Persson, J.L., Wolgemuth, D.J., 2005. Induction of apoptosis involving multiple pathways is a primary response to cyclin A1-deficiency in male meiosis. Dev. Dyn. 234, 114-123.

Schafer, K.A., 1998. The cell cycle: a review. Vet. Pathol. 35, 461-478.

Schwartz, G.K., Shah, M.A., 2005. Targeting the cell cycle: a new approach to cancer therapy. J. Clin. Oncol. 23, 9408-9421.

Shack, S., Wang, X.T., Kokkonen, G.C., Gorospe, M., Longo, D.L., Holbrook, N.J., 2003. Caveolin-induced activation of the phosphatidylinositol 3-kinase/Akt pathway increases arsenite cytotoxicity. Mol. Cell. Biol. 23, 2407-2414.

Sheiness, D., Fanshier, L., Bishop, J.M., 1978. Identification of nucleotide sequences which may encode the oncogenic capacity of avian retrovirus MC29. J. Virol. 28, 600-610.

Sherr, C.J., 1996. Cancer cell cycles. Science 274, 1672-1677.

Sherr, C.J., 2001. The INK4a/ARF network in tumour suppression. Nat. Rev. Mol. Cell. Biol. 2, 731-737.

Shi, L., Chen, G., He, D., Bosc, D.G., Litchfield, D.W., Greenberg, A.H., 1996. Granzyme B induces apoptosis and cyclin A-associated cyclindependent kinase activity in all stages of the cell cycle. J. Immunol. 157, 2381-2385.

Shi, Y., Glynn, J.M., Guilbert, L.J., Cotter, T.G., Bissonnette, R.P., Green, D.R., 1992. Role for c-myc in activation-induced apoptotic cell death in T cell hybridomas. Science 257, 212-214.

Shim, H., Chun, Y.S., Brian, C., Lewis, B.C., Dang, C.V., 1998. A unique glucose-dependent apoptotic pathway inducedbyc-Myc. Proc. Natl. Acad. Sci. U.S.A. 95, 1511-1516.

Shimizu, T., O’Connor, P.M., Kohn, K.W., Pommier, Y., 1995. Unscheduled activation of cyclin $\mathrm{B} 1 / \mathrm{Cdc} 2$ kinase in human promyelocytic leukemia cell line HL60 cells undergoing apoptosis induced by DNA damage. Cancer Res. 55, 228-231.

Shin, I., Yakes, F.M., Rojo, F., Shin, N.Y., Bakin, A.V., Baselga, J., Arteaga, C.L., 2002. PKB/Akt mediates cell-cycle progression by phosphorylation of p27(Kip1) at threonine 157 and modulation of its cellular localization. Nat. Med. 8, 1145-1152.

Shtivelman, E., Sussman, J., Stokoe, D., 2002. A role for PI 3-kinase and PKB activity in the G2/M phase of the cell cycle. Curr. Biol. 12,919-924.

Siegel, R.M., 2006. Caspases at the crossroads of immune-cell life and death. Nat. Rev. Immunol. 6, 308-317.

Smith, M.L., Kontny, H.U., Bortnick, R., Fornace Jr., A.J., 1997. The p53regulated cyclin $\mathrm{G}$ gene promotes cell growth: p53 downstream effectors cyclin $\mathrm{G}$ and Gadd45 exert different effects on cisplatin chemosensitivity. Exp. Cell Res. 230, 61-68.

Sofer-Levi, Y., Resnitzky, D., 1996. Apoptosis induced by ectopic expression of cyclin D1 but not cyclin E. Oncogene 13, 2431-2437. 
Spencer, C.A., Groudine, M., 1991. Control of c-myc regulation in normal and neoplastic cells. Adv. Cancer Res. 56, 1-48.

Stambolic, V., Suzuki, A., de la Pompa, J.L., Brothers, G.M., Mirtsos, C., Sasaki, T., Ruland, J., Penninger, J.M., Siderovski, D.P., Mak, T.W., 1998. Negative regulation of PKB/Akt-dependent cell survival by the tumor suppressor PTEN. Cell 95, 29-39.

Steiner, P., Rudolph, B., Muller, D., Eilers, M., 1996. The functions of Myc in cell cycle progression and apoptosis. Prog. Cell Cycle Res. 2, 73-82.

Stroh, C., Cassens, U., Samraj, A.K., Sibrowski, W., Schulze-Osthoff, K., Los, M., 2002. The role of caspases in cryoinjury: caspase inhibition strongly improves the recovery of cryopreserved hematopoietic and other cells. FASEB J. 16, 1651-1653.

Sweeney, C., Murphy, M., Kubelka, M., Ravnik, S.E., Hawkins, C.F., Wolgemuth, D.J., Carrington, M., 1996. A distinct cyclin A is expressed in germ cells in the mouse. Development 122, 53-64.

Tenjo, T., Toyoda, M., Okuda, J., Watanabe, I., Yamamoto, T., Tanaka, K., Ohtani, M., Nohara, T., Kawasaki, H., Tanigawa, N., 2000. Prognostic significance of p27(kip1) protein expression and spontaneous apoptosis in patients with colorectal adenocarcinomas. Oncology 58, 45-51.

Vairo, G., Soos, T.J., Upton, T.M., Zalvide, J., DeCaprio, J.A., Ewen, M.E., Koff, A., Adams, J.M., 2000. Bcl-2 retards cell cycle entry through p27(Kip1), pRB relative p130, and altered E2F regulation. Mol. Cell. Biol. 20, 4745-4753.

Vanhaesebroeck, B., Alessi, D.R., 2000. The PI3K-PDK1 connection: more than just a road to PKB. Biochem. J. 346 Pt 3, 561-576.

Vassilev, L.T., Tovar, C., Chen, S., Knezevic, D., Zhao, X., Sun, H., Heimbrook, D.C., Chen, L., 2006. Selective small-molecule inhibitor reveals critical mitotic functions of human CDK1. Proc. Natl. Acad. Sci. U.S.A. 103, 10660-10665.

Vennstrom, B., Sheiness, D., Zabielski, J., Bishop, J.M., 1982. Isolation and characterization of c-myc, a cellular homolog of the oncogene (v-myc) of avian myelocytomatosis virus strain 29. J. Virol. 42, 773-779.

Vermeulen, K., Van Bockstaele, D.R., Berneman, Z.N., 2003. The cell cycle: a review of regulation, deregulation and therapeutic targets in cancer. Cell Prolif. 36, 131-149.

Vieira, H.L., Boya, P., Cohen, I., El Hamel, C., Haouzi, D., Druillenec, S., Belzacq, A.S., Brenner, C., Roques, B., Kroemer, G., 2002. Cell permeable BH3-peptides overcome the cytoprotective effect of Bcl-2 and Bcl-X(L). Oncogene 21, 1963-1977.

Vivanco, I., Sawyers, C.L., 2002. The phosphatidylinositol 3-Kinase AKT pathway in human cancer. Nat. Rev. Cancer 2, 489-501.

Wadler, S., 2001. Perspectives for cancer therapies with cdk2 inhibitors. Drug Resist. Updates 4, 347-367.

Walensky, L.D., Kung, A.L., Escher, I., Malia, T.J., Barbuto, S., Wright, R.D., Wagner, G., Verdine, G.L., Korsmeyer, S.J., 2004. Activation of apoptosis in vivo by a hydrocarbon-stapled BH3 helix. Science 305, $1466-1470$.
Wang, C.Y., Mayo, M.W., Korneluk, R.G., Goeddel, D.V., Baldwin Jr., A.S., 1998. NF-kappaB antiapoptosis: induction of TRAF1 and TRAF2 and c-IAP1 and c-IAP2 to suppress caspase-8 activation. Science 281, $1680-1683$.

Wang, J.M., Chao, J.R., Chen, W., Kuo, M.L., Yen, J.J., Yang-Yen, H.F., 1999. The antiapoptotic gene mcl-1 is up-regulated by the phosphatidylinositol 3-kinase/Akt signaling pathway through a transcription factor complex containing CREB. Mol. Cell. Biol. 19, 6195-6206.

Watson, A.J.M., 2006. An overview of apoptosis and the prevention of colorectal cancer. Crit. Rev. Oncol. Hematol. 57, 107-121.

Wechsler-Reya, R., Elliott, K., Herlyn, M., Prendergast, G.C., 1997. The putative tumor suppressor BIN1 is a short-lived nuclear phosphoprotein, the localization of which is altered in malignant cells. Cancer Res. 57, 3258-3263.

Wesselborg, S., Lauber, K., 2005. Mechanism of anticancer drug action. In: Los, M., Gibson, S.B. (Eds.), Apoptotic Pathways as Target for Novel Therapies in Cancer and Other Diseases. Springer Academic Press, New York.

Wolowiec, D., Deviller, P., Simonin, D., Souchier, C., Rimokh, R., Benchaib, M., Bryon, P.A., Ffrench, M., 1995. Cdk1 is a marker of proliferation in human lymphoid cells. Int J Cancer 61, 381-388.

Yan, Y., Frisen, J., Lee, M.H., Massague, J., Barbacid, M., 1997. Ablation of the CDK inhibitor p57Kip2 results in increased apoptosis and delayed differentiation during mouse development. Genes Dev. 11, 973983.

Yang, L., Li, N., Wang, C., Yu, Y., Yuan, L., Zhang, M., Cao, X., 2004. Cyclin L2, a novel RNA polymerase II-associated cyclin, is involved in pre-mRNA splicing and induces apoptosis of human hepatocellular carcinoma cells. J. Biol. Chem. 279, 11639-11648.

You, H., Pellegrini, M., Tsuchihara, K., Yamamoto, K., Hacker, G., Erlacher, M., Villunger, A., Mak, T.W., 2006. FOXO3a-dependent regulation of Puma in response to cytokine/growth factor withdrawal. J. Exp. Med. 203, 1657-1663.

Yu, Q., 2006. Restoring p53-mediated apoptosis in cancer cells: new opportunities for cancer therapy. Drug Resist. Updates 9, 19-25.

Yuan, J., Yan, R., Kramer, A., Eckerdt, F., Roller, M., Kaufmann, M., Strebhardt, K., 2004. Cyclin B1 depletion inhibits proliferation and induces apoptosis in human tumor cells. Oncogene 23, 5843-5852.

Zhou, B.P., Liao, Y., Xia, W., Spohn, B., Lee, M.H., Hung, M.C., 2001. Cytoplasmic localization of p21Cip1/WAF1 by Akt-induced phosphorylation in HER-2/neu-overexpressing cells. Nat. Cell Biol. 3, 245252.

Zindy, F., Quelle, D.E., Roussel, M.F., Sherr, C.J., 1997. Expression of the p16INK4a tumor suppressor versus other INK4 family members during mouse development and aging. Oncogene 15, 203-211.

Zinkel, S., Gross, A., Yang, E., 2006. BCL2 family in DNA damage and cell cycle control. Cell Death Differ. 13, 1351-1359. 